\title{
Unidad de las iglesias y ministerios *
}

\author{
(COMENTARIO TEOLÓGICO-ECUMÉNICO AL CAPITULO III \\ DE LA «LUMEN GENTIUM»)
}

El drama de la desunión de los cristianos, si doloroso en el pasado, lo es hoy con mayor intensidad. A ello contribuyen motivos de muy distinta índole, de los cuales se me ocurre recoger aquí algunos más sobresalientes.

En primer lugar, el fenómeno en sí mismo, que resulta bastante inexplicable. Es doloroso, e incluso absurdo, que los cristianos, que creen en Cristo y le confiesan su «único Señor y Salvador, quien, dando su vida por los hombres, les llama con su servicio a descubrir el sentido de su existencia y la plenitud de una nueva humanidad ${ }^{1}$ se encuentren divididos por razón de su fe. La fe es, antes que nada, creer en alguien. No creer algo. Frente a lo primero, todo lo demás tiene un carácter prácticamente secundario.

En segundo lugar, el descubrimiento de la historicidad de la verdad. Un hecho real, aunque difícil de caracterizar. Un hecho que supera y rompe los moldes de unas afirmaciones que pudieron hacerse en otro tiempo como consecuencia de unos conceptos esencialistas inmutables. Un hecho que tritura el dogmatismo a ultranza. ¿No ha estado dicho dogmatismo, con una frecuencia que hoy nos desconcierta, en la base de muchas divisiones cristianas? Y lo malo no es que haya estado, cosa explicable desde la historia; lo grave es que sigue estando como consecuencia de un excesivo celo dogmático. Los filósofos modernos han acabado con el concepto de una verdad que se situaba más allá de la historia. Ellos nos han dado la óptica para reconocer 0 , al menos, sospechar las limitaciones de lo que formulamos como verdad. $Y$ ello, sin olvidar que la verdad no es algo simplemente teórico, sino que tiene que ha-

* Tras este artículo hay una abundante literatura, cuyos títulos me parece improcedente recoger aquí. Basta con dar la referencia de las citas. Esa literatura es, en gran parte, de carácter ecuménico. Responde, por tanto, al punto de vista adoptado en el artículo. Lo cual conlleva unos criterios hermenéuticos muy específicos. De no tenerlos en cuenta, muchas de las cosas aquí afirmadas resultan extrañas y hasta escandalosas.

1. GRUPOS de DOMBES, «Para una reconciliación de los ministerios»: Seminarios 57-58 (1975-536. 
cerse $y$, en este sentido, se presenta siempre como un proceso inacabado. La "ortodoxia» ya no se puede considerar como criterio exclusivo de verdad. A ella tiene que añadirse la "ortopraxis». Ortodoxia y ortopraxis trabajando en una dialéctica constante, inacabada, dejando siempre abierto el futuro. La historicidad de la verdad hace menos comprensible los exclusivismos formulados en razón de un excesivo dogmatismo. Por ello, hace también más incomprensible la separación de los cristianos nacida al influjo de un dogmatismo hoy superado.

En tercer lugar, la fisonomía del mundo moderno. El mundo moderno trata de superar los nacionalismos radicales, para correr hacia una comunidad humana cada vez más universal y compacta. Se han roto muchas fronteras, que antes resultaban insalvables y constituían causa de separación para los pueblos. Es verdad que esta aspiración del mundo moderno está oscurecida por múltiples intereses creados que hace de ella prácticamente una utopía. Pero la aspiración, como tal, está presente en la conciencia del mundo moderno.

«Siempre se ha esforzado el hombre con su trabajo y con su ingenio en perfeccionar su vida, pero en nuestros días, gracias a la ciencia y a la técnica; ha logrado dilatar y sigue dilatando el campo de su dominio sobre casi toda la naturaleza, $y$, con ayuda sobre todo del aumento experimentado por los diversos medios de intercambio entre las naciones, la familia humana se va sintiendo y haciendo una única comunidad en el mundo" ${ }^{2}$.

«Hoy la humanidad se aprehende, se piensa, por primera vez en el curso de su historia, como humanidad. Esto se traduce no tanto por ia planetarización de los medios de transporte o de comunicación de masas, sino más bien por la conciencia de una unidad de destino de todos los hombres. La humanidad llega a ser más y más sujeto de su propia historia» ${ }^{3}$.

Es verdad que el mundo moderno está afectado por una profunda crisis religiosa, cuyas causas no son, ni mucho menos, todas negativas. Lo cual se puede considerar como un dato negativo en la construcción de ese mundo del futuro. Pero ello no oscurece fundamentalmente esa aspiración positiva que aquí se ha recogido.

Todo este contexto nuevo de la humanidad golpea sorda y crudamente la conciencia cristiana. Frente a un mundo que aspira a la unidad universal es paradójica la realidad de una iglesia dividida internamente e incapaz, por ef mismo hecho, de llevar a ese mundo roto religiosamente el mensaje de la salvación que Dios le ofrece en Jesús de Nazaret. Si es vital para la iglesia llevar a cabo la misión encomendada, lo es también acelerar el paso para llegar a la meta de la unidad. Sin ello, su predicación y la vivencia de su mensaje estarán siempre sometidas a un grave proceso de inflación.

2. GS. 33a.

3. B. D. DUPUY, «La conferencia de Lovaina (2-12 de agosto-1971)»: /stina 3 (1971) 270. 
Desde hace bastante tiempo las iglesias están tomando el pulso a la magnitud de este problema. Son reveladoras, al respecto, las palabras del Vaticano Il en el proemio del decreto sobre el ecumenismo:

«Promover la restauración de la unidad entre todos los cristianos es uno de los fines principales que se ha propuesto el sacrosanto concilio Vaticano II, puesto que única es la iglesia fundada por Cristo Señor, aún cuando son muchas las comuniones cristianas que se presentan a los hombres como la herencia de Jesucristo. Los discípulos del Señor piensan de diverso modo y siguen distintos caminos, como si Cristo mismo estuviera dividido (cf. 1 Cor $1,13)$. División que abiertamente repugna a la voluntad de Cristo y es piedra de escándalo para el mundo y obstáculo para la causa de la difusión del Evangelio por todo el mundon ${ }^{4}$.

Todos los documentos que, en el plano interconfesional, tratan el problema de los ministerios, se hacen eco de este mismo deseo. Ellos expresan su inquietud por la validez del testimonio de la iglesia, mientras ella no consiga la unidad, a la que la voluntad expresa de su fundador divino hace referencia con estas imperativas palabras: "Mas no os ruego solamente por éstos, sino también por los que han de creer en mi por la palabra de ellos; para que todos sean una cosa, como tú, oh Padre, estás en mí y yo en ti, que también ellos estén en nosotros, para que el murido crea que tú me enviaste») (Jn 17, 20-21). La desunión de los cristianos compromete, por tanto, la validez de su testimonio en favor de Cristo.

"La iglesia en cuanto comunidad reconciliada y reconciliadora, no puede responder al plan de Dios sobre el mundo mientras se halle desgarrada por divisiones y desacuerdos. Los miembros de la iglesia, donde quiera que se hallen, forman parte de un mismo pueblo, un cuerpo único de Cristo, cuya misión consiste en ser un signo precursor y eficaz de la unificación final de todas las cosas, en donde Dios será todo en todos» ${ }^{5}$.

En un problema de tal envergadura no bastan simplemente los deseos. Es necesario pasar a la acción, a fin de ver hasta qué punto estamos en presencia o no de un deseo sincero. Un deseo que toma en serio las cosas y se pone en marcha, para superar aquellos obstáculos que impiden la conquista de la meta de la unidad.

La iglesia católica romana, como agrupación más numerosa de creyentes en Cristo, tiene, al respecto, una responsabilidad particular. ¿Ha tomado conciencia de ella? El análisis teológico-ecuménico del capítulo III de la LG. nos lo va a decir.

El capítulo III de la LG. trata de la constitución jerárquica de la iglesia y en particular del episcopado. Por tanto, se refiere a los ministerios en la iglesia,

4. UR. Proëmio.

5. GRUPO teológico luterano-católico de Estados Unidos, «El Primado del Papa»: Seminarios $57-58$ (1975) 490 . 
que, como es sabido, centra uno de los problemas del diálogo interconfesional. Problema que hay que resolver como medida previa a la conquista de la deseada meta de la unidad. Y ello es así, porque, sin solucionar el problema del ministerio, es imposible llegar a la intercomunión, paso necesario y decisivo en la conquista de la unidad.

Para lograr un análisis profundo del capítulo III de la LG. voy a dividir el trabajo en dos apartados: A.- Luces. B.- Sombras.

A.- Luces. La eclesiología tradicional de la iglesia católica romana padecía, desde tiempo atrás, una serie de males profundos. El Padre Congar, en múltiples lugares, califica a dicha eclesiología de jerarcología.

"A pesar de interesantes incentivos de renovación, de que trataremos más adelante; la iglesia era presentada hacia 1930 (fecha de mi ordenación sacerdotal) como una sociedad organizada, que se constituía por el ejercicio de poderes de los que el papa, los obispos y sacerdotes estaban investidos. La eclesiología consistía casi exclusivamente en un tratado de derecho público. Yo creé, para caracterizarla, la palabra 'jerarcología', que con frecuencia se ha venido usando después! ${ }^{6}$.

Con ello se caía en una serie de inconvenientes graves. Se confundía iglesia con jerarquía. Esta aparecía elemento dominador y separado. Sobre ella gravitaba la total responsabilidad de la misión de la Iglesia. Y el clero se alzaba como un elemento contrapuesto al pueblo de Dios. Una eclesiología acuñada de esta manera, llevaba necesariamente a un fuerte clericalismo y a un olvido casi total de la iglesia como pueblo de Dios.

Los males, que se producen en esta línea, no quedan aquí. La eclesiología católica romana ha estado dominada, en gran parte, por la enseñanza del Vaticano I acerca del papado. Si Congar habla de esta eclesiología en la forma antes reseñada, es decir, como tratado de la jerarquía, bien se puede afirmar que, tras el Vaticano I, se puede hablar de una «papalogía». El papa, tal y como lo concibe el Vaticano l, puede conducir a la impresión, y de hecho ha conducido, de que es el todo en la iglesia. Los obispos, siempre en el ámbito de esta impresión, vendrían a ser meros delegados suyos. Que esta. impresión no es un mito lo prueba el famoso despacho circular de Bismarck a lás cancillerías el 14 de mayo de 1872. En él presenta a los obispos como meros delegados del papa. Los obispos alemanes salieron al paso de este mal entendido con una carta en la que se defiende la autoridad episcopal como recibida directamente de Cristo. Los obispos ńo son delegados del papa. Son

6. Y. M. CONGAR, Ministerios y comunión eclesial (Madrid 1973) 12. 
pastores de sus diócesis, con todo lo que ello lleva consigo por voluntad de Cristo. Pío IX alabó y aprobó la postura del episcopado alemán ${ }^{7}$.

La doctrina, en verdad, es así. Pero la praxis centralizadora, seguida por Roma, a partir sobre todo del Vaticano I, no puede, por menos, de producir la impresión de que el papa es el todo en la iglesia y que los obispos están sólo para secundar las iniciativas de Roma. La eclesiología post-Vaticano l era, en la praxis, una monarquía religiosa.

Finalmente, y no es ello un mal que carezca de importancia, la eclesiología católica romana se caracterizaba por una excesiva dosis de juridicismo. Era consecuencia lógica de su presentación y definición de iglesia como sociedad perfecta. En esta visión lo más importante está en que todo funcione con la máxima garantía. Se busca eficacia y disciplina. Para ello se impone el montaje de un complejo, sinuoso en ocasiones, y abundante aparato jurídico. Hay que atar bien todos los cabos, para que todo funcione como una máquina perfecta. La iglesia, como misterio, queda en el olvido o en la penumbra. Al Espíritu se le acepta con disgusto. Puede enredar las cosas. Puede comprometer los cálculos de la jerarquía y trastrocar sus planes. Resulta, por consiguiente, un elemento incómodo, al que con frecuencia se le margina.

Esta eclesiología, tan poco coherente con los datos de la revelación y de la tradición primitiva, traspasa los mismos umbrales el Vaticano II. El esquema, elaborado por la comisión previa al Concilio, es un esquema basado en los postulados de una eclesiología tradicional. De haberlo llevado a efecto, no hubiera sido alumbrada la constitución «Lumen Gentium». Afortunadamente los padres del Concilio se dan cuenta del problema. Se rechaza el esquema elaborado, después de múltiples elaboraciones, cuyas alternativas no interesa recoger aquí, se presenta y prueba la constitución dogmática de la iglesia.

$Y$ a fe que ella nos depara sorpresas muy agradables, logros insospechados en la transformación de la eclesiología tradicional católica romana. Desde las primeras líneas se supera el profundo juridicismo, que esclerotizaba la vitalidad interna de la iglesia. Se declara que «la iglesia es en Cristo como un sacramento o señal e instrumento de la íntima unión con Dios y de la unidad de todo el género humano» 7 . "El Espíritu habita en la iglesia y en los corazones de los fieles como en un templo $(1$ Cor 3,$16 ; 6,19)$ y en ellos ora y da testimonio de la adopción de hijos (cf. Gal 4,6; Rom 8, 15-16 y 26). Con diversos dones jerárquicos y carismáticos dirige y enriquece con todos sus frutos a la iglesia (cf. Ef. 4, 11-12; 1 Cor 12,4; Gal 5,22), a la que guía hacia toda verdad (cf. Jn 16,13) y unifica en comunión y ministerio. Hace rejuvenecer a la iglesia, la renueva constantemente y la conduce a la unión consumada con su Es-

7. O. ROUSSEAU, «El verdadero valor del episcopado en la Iglesia según el importante documento de 1875»): Irenikon 29 (1956) 130.

7a. LG. 1. 
poso. Pues el Espíritu y la Esposa dicen al Señor Jesús: ¡Ven! (cf. Ap. $22,17)_{11}{ }^{8}$.

Esta nueva visión eclesiológica, a través de la cual se presenta a la iglesia como misterio, es enormemente valorada por teólogos de otras confesiones. Juan Bocs, el llorado teólogo reformado, dice:

«Es manifiesto que la constitución sobre la iglesia señala un cambio profundo en la perspectiva eclesiológica de la iglêsia católica romana. Esta, en efecto, ha estado dominada en el curso del período postridentino por una concepción que se consideraba ante todo como sociedad visible y que, en consecuencia, ponía el acento en su estructura jerárquica y jurídica. La iglesia de Jesucristo se identificaba en ella prácticamente con la institución católica romana.

Ahora bien, la Lumen Gentium comienza por captar a la iglesia en el plano del misterio y ve la fuente de este misterio en la elección divina” ${ }^{9}$.

La auténtica novedad, el giro que bien puede llamarse copernicano, se encuentra en el capítulo II. Mientras los esquemas anteriores colocaban en este capítulo a la jerarquía, con lo que se indicaba estar en el camino de la eclesiología tradicional, la Lumen Gentium pone ahora al pueblo de Dios. La iglesia, por tanto es presentada en primer lugar como pueblo de Dios. De aquí emerge luego todo lo demás, $y$, en concreto, la jerarquía o, mejor, los ministerios. Los ministros ya no tienen por qué presentarse como algo al margen y por encima del pueblo de Dios. Ellos, son en primer término, pueblo de Dios.

Una valoración de este hecho nos la da Juan Bocs con las siguientes palabras:

«El capítulo, así titulado, viene manifiestamente a confirmar el cambio de perspectiva, que hemos destacado a propósito del capítulo primero. Muestra igualmente cómo en el curso mismo del Concilio esta evolución se ha hecho más consciente y deliberada. En efecto, al principio de la segunda sesión el nuevo esquema remitido a los padres, comprendía después de la exposición sobre el misterio de la iglesia, un capítulo consagrado a la constitución jerárquica, y luego un tercero titulado: 'del pueblo de Dios y especialmente de los seglares'; era como decir que la jerarquía preside la manifestación del misterio. Pero desde octubre de 1963 ese plan quedó modificado; el capítulo sobre el pueblo de Dios se convertía en el capítulo segundo; $y$, aunque algunos de esos elementos estaban tomados del capítulo tercero, representaban, sin embargo, un conjunto nuevo" ${ }^{10}$.

Al adoptar este punto de vista, la eclesiología católica romana vuelve a la auténtica tradición bíblica. En efecto, lo que prima en Jesús, desde el momen-

8. LG. 4 .

9. J. BOCS, Puntos de vista de los teólogos protestantes sobre el Vaticano // (Madrid 1969) 16

10. J. BOCS, Puntos de vista, 21-22. 
to en que elige a los Doce, germen del nuevo pueblo de Dios, es poner en marcha a ese pueblo, heredero de las antiguas promesas y beneficiario de la nueva alianza consagrada en su sangre. "Pacto nuevo que estableció Cristo, es decir, el Nuevo Testamento en su sangre (cf. 1 Cor 11,25), convocando un pueblo de entre los judíos y gentiles, que se condensara en unidad no según la carne, sino en el Espíritu, y constituyera un nuevo pueblo de Diosii ".

Esta declaración de principio es utópica, si no se ha ahondado en la realidad profunda de este pueblo y en las consecuencias que ahí se derivan. Como tal es «linaje escogido, sacerdocio real, nación santa, pueblo de adquisición... que en un tiempo no era pueblo y ahora es pueblo de Dios» (1 P 2, 9-10).

«Todos los que están unidos con Jeșús en tanto que Cristo y Señor por el bautismo y la fe, están anidos y participan en su sacerdocio. Reconocemos, por consiguiente, que la iglesia entera tiene un sacerdocio en Cristo, es decir, un ministerio o servicio de Dios a los hombres, para que a la 'vista de vuestras buenas obras den gloria a Dios en el día de vuestra visita' (1 P 2,12). La iglesia tiene, por consiguiente, el privilegio y la obligación de representar los intereses de Dios a los hombres y los de los hombres a Dios" ${ }^{12}$.

Como pueblo de Dios, tiene sus derechos y obligaciones. «Tiene por suerte la dignidad y libertad de los hijos de Dios, en cuyos corazones habita el Espíritu Santo como en su templo. Tiene por ley el mandato del amor, como el mismo Cristo nos amó (cf. Jn 13,34). Tiene últimamente como fin la dilatación del reino de Dios, incoado por el mismo Dios, hasta que sea consumado por Él mismo al fin de los tiempos, cuando se manifieste Cristo nuestra vida (cf. Col 3,4)... Constituido por Cristo en orden a la comunión de vida, es empleado también por Él como instrumento de la redención universal y es enviado a todo el mundo como luz del mundo y sal de la tierra (cf. Mat. 5, 13-16) ${ }^{13}$.

«La iglesia tiene, por consiguiente, la misión de proclamar el Evangelio a todos, creyentes y no creyentes. Esta misión o servicio de toda la iglesia es llamada ministerio (diaconía) ${ }^{14}$.

La condición sacerdotal del pueblo de Dios da un sentido nuevo a toda la vida del cristiano. Todas sus acciones quedan vinculadas de una forma peculiar con Dios-Padre por medio de Jesucristo en el Espíritu Santo. «Por ello todos los discípulos de Cristo, perseverando en la oración y alabanza a Dios (cf. Hech 2, 42-47), han de ofrecerse a sí mismo como hostia viva, santa y grata a Dios (cf. Rom 12,1); han de dar testimonio de Cristo en todo lugar y, a quien

11. GRUPO teológico luterano-católico de Estados Unidos, «Eucaristla y ministerios»: Seminarios 57-58 (1975) 471.

12. LG. $9 a$.

13. LG. $9 b$

14. GRUPO teológico luterano-católico de Estados Unidos, Eucarist/a, 471. 
se lo pidiere, han de dar también razón de la esperanza que tienen en la vida eterna (cf. 1 P 3,15 )» ${ }^{15}$.

"Cada miembro del cuerpo de Cristo está llamado y habilitado para vivir su fe y para dar testimonio de ella en medio de sus hermanos por el servicio del amor y la justicia, por la irradiación de la esperanza. Así, en cada lugar, la comunidad cristiana da testimonio de la reconciliación, que ella vive y llama a todos los hombres a dejarse reconciliar con Dios y entre ellos»" ${ }^{16}$.

El reconocimiento profundo, què el concilio hace de la condición del cristiano, no acaba aquí. No sólo reconoce su sacerdocio, sino que también se proclama su profetismo. "El pueblo santo de Dios participa también del don profético de Cristo, difundiendo su vivo testimonio sobre todo por la vida de fe y caridad, ofreciendo a Dios el sacrificio de la alabanza, el fruto de los labios que bendicen su nombre (cf. Hebr 13,15). La universalidad de los fieles, que tiene la unción del Santo (cf. 1 Jn 2,20 y 27) no puede fallar en su creencia y ejerce esta su peculiar propiedad mediante el sentido sobrenatural de la fe de todo el pueblon ${ }^{17}$.

Evidentemente, el Vaticano II pone las bases eclesiológicas para una valoración profunda del pueblo de Dios. Con ello se supera la visión empobrecida del cristiano, del simple fiel, a quien se condenaba a una especie de ostracismo en la vida de la iglesia. Consciente o inconsciente, era considerado como un minorenne, a quien la jerarquía debía cuidar y atender. ¿No ha ido por este camino la ingerencia excesiva del magisterio, cortando cualquier iniciativa que pudiera presentar simple apariencia de desvío? Todo esto era simple consecuencia de una visión eclesiológica en la que la autoridad realizaba una acción absorbente. Los laicos representaban muy poco en la iglesia y su actitud tenía que ser, por necesidad, profundamente pasiva. De esto se hace eco Congar al principio de su libro Jalones para una teología del laicado» con estas palabras: «El cardenal Gasquet refiere esta anécdota: un catecúmeno preguntaba a un sacerdote católico cual era la posición del laico en su iglesia. La posición del laico en nuestra iglesia, respondía el sacerdote, es doble. Él se pone de rodillas delante del altar, es su primera postura; él se coloca de cara al público, es su segunda postura. El cardenal Gasquet añadía: se olvidaba una tercera: meter la mano en su portamonedas»" ${ }^{18}$.

El capítulo segundo de la Lumen Gentium constituye una verdadera revolución en la eclesiología tradicional de la iglesia católica romana. Se pasa de una eclesiología de castas, de dirigentes, a una eclesiología del pueblo de Dios. He aquí la verdadera revolución del documento conciliar. Se trata del logro más importante conseguido por el Vaticano II. $Y$ las perspectivas que

\footnotetext{
15. LG. $10 \mathrm{a}$.

16. GRUPO de DOMBES, Para una reconciliación de los ministerios, 537.

17. LG. 12 a.

18. Y. M. CONGAR, Jalones para una teología del laicado (París 1954) 7.
} 
con él se abren pueden ser, hasta cierto punto, imprevisibles, si no se atenazan desde fuera. En principio, se puede afirmar sin género de dudas, que esta forma de visualizar la eclesiologíą responde mucho mejor al dato bíblico $y$ desbroza el camino para un encuentro con las iglesias separadas de Roma, principalmente de la Reforma. Toda la iglesia, no sólo los ministros, recibe la misión de llevar el evangelio al mundo. Y, desde esta misión, fundamental y prioritaria, adquiera sentido y valor todo servicio en la iglesia. Si se rompe esta conexión, se desvirtúa radicalmente la razón y el sentido de los demás ministerios. Y se cae, como de hecho ha sucedido, en una visión de los ministerios que termina por ser dominadora y totalitaria. No son los ministerios los que están al servicio del pueblo de Dios, sino el pueblo de Dios al servicio de los ministros. La visión de la iglesia, como pueblo de Dios en sentido prioritario, es el punto clave de la eclesiología que se mueve en ambientes ecuménicos. De ello tenemos este testimonio preclaro de la comisión 'Fe y Constitución' del Consejo Ecuménico de las iglesias (C. E. I.) Dice así:

"La iglesia, en tanto que comunión en el Espíritu Santo, está llamada a proclamar y prefigurar el Reino de Dios, anunciando el Evangelio al mundo y estando edificada como cuerpo de Cristo. Dentro del cuadro de estas dos misiones, cada miembro del Cuerpo está llamado a vivir su fe y a dar cuenta de su esperanza. Cada uno se mantiene al lado de los hombres y de las mujeres, con sus alegrías y sufrimientos, y da testimonio entre ellos por medio de un servicio de amor fraterno; cada uno lucha con los oprimidos con vista a esa libertad y a esa dignidad prometidas con la venida del reino" ${ }^{19}$.

El capítulo segundo de la Lumen Gentium sitúa en su verdadera óptica el problema de los ministerios. Los ministros no están fuera, como enfrentados al pueblo de Dios, o por encima como dominadores. Los ministros sirven al pueblo de Dios del que forman parte. Sus ministerios brotan del ministerio de toda la iglesia. Significativa es, al respecto, la declaración del grupo interconfesional luterano-católico de Estados Unidos. "La iglesia tiene, por consiguiente, la misión de proclamar el Evangelio a todos, creyentes y no creyentes. Esta misión o servicio de toda la iglesia es llamada ministerio (diaconía)... estamos convencidos de que el ministerio especial no puede ser discutido aparte, sino en el contexto del ministerio de todo el pueblo de Dios» ${ }^{20}$.

El problema de los ministerios me sitúa de lleno en el centro del contenido de este artículo. No hay que olvidar que se intenta hacer un comentario o análisis teológico-ecuménico del capítulo tercero de la Lumen Gentium que trata, por cierto, de la constitución jerárquica de la iglesia.

19. COMISIÓN de fe y constitución del C.E.I., «Documento de Accra»: Seminarios 57-58 (1975) 471.

20. GRUPO teológico luterano-católico de Estados Unidos, Eucaristía, 472. 
Desde la perspectiva de los ministerios, todas las iglesia cristianas están comprometidas en una labor ecuménica, pues ellos constituyen uno de los puntos más conflictivos y densos, cuando se aborda el tema de la unidad de los cristianos. Importa, por tanto, ver imparcialmente y juzgar objetivamente qué aporta o no aporta el Vaticano Il a la solución del problema de los ministerios, debrozando así el camino de la unidad. De momento, interesa ver qué aporta, pues estoy en la perspectiva de las "Luces», o, lo que es lo mismo, trato de recoger los aspectos positivos de la doctrina del Vaticano II acerca de los ministerios.

Ante todo, se impone recordar brevemente lo que se ha dicho sobre el nuevo enfoque de la eclesiología del Vaticano II. Nuevo enfoque del cual es digno sobresaliente el capitulo segundo. Por lógica interna, este capítulo proyecta su luz intensa sobre el capítulo tercero, que trata precisamente de la constitución jerárquica de la iglesia, o sea, de los ministerios en una perspectiva limitada, pues apenas se refiere en amplitud y profundidad a los obispos. Recordemos que la eclesiología del Vaticano II ya no es, en su núcleo, la eclesiología que se preocupaba casi exclusivamente de la jerarquía. La eclesiología del Vaticano II es una eclesiología del pueblo de Dios con la cual se supera lo que Hans Küng ha llamado, en algunas ocasiones, el estrangulamiento clerical. La jerarquía no aparece ya con carácter de dominio, sino de servicio. Es necesaria, porque la iglesia nunca puede ser á-crata. Pero se sitúa en el pueblo y para el pueblo. Nunca encima ni por delante del pueblo. Una jerarquía en estas condiciones rompería la unidad del cuerpo de Cristo y perdería su razón de ser. Las primeras pinceladas del Vaticano II sobre el tema, son sugestivas en extremo: «Para apacentar el pueblo de Dios y acrecentarlo siempre, Cristo Señor instituyó en su iglesia diversos ministerios ordenados al bien de todo el cuerpo. Porque los ministros, que poseen la sagrada potestad están al servicio de sus hermanios, a fin de que todos cuantos son miembros del pueblo de Dios y gozan, por tanto, de la dignidad cristiana tiendan todos libre y ordenadamente a un mismo fin y lleguen a la salvación " ${ }^{21}$.

Esta forma de presentar los ministerios encaja perfectamente en los esquemas ecuménicos. No causa, con seguridad, ninguna extorsión. No desentona de los modelos que se siguen en ambientes interconfesionales. Véase la similitud de presentación y lenguaje que las palabras del Vaticano II tienen con algunas formulaciones de carácter ecuménico.

«El ministro, dice el Grupo de Dombes, es miembro de la comunidad y también ante ella es un 'enviado' que ella recibe de Cristo. Sus funciones marcan en la existencia eclesial la prioridad de la iniciativa y de la autoridad divina, la continuidad de la misión en el mundo, el vínculo de comunión establecido por Cristo entre las diversas comunidades en la unidad de la iglesia» 22.

21. LG. 18a.

22. GRUPO de Dombes, Para una reconciliación de los ministerios, 538. 
Por eso, la forma de expresión vaticana es acogida con simpatía por representantes cualificados de otras iglesias cristianas. Lo cual es signo inequívoco de que el Vaticano II se encuentra en la línea profundamente ecuménica, para lo cual, ha tenido que realizar una profunda labor de transformación tanto de lenguaje como de contenido:

"Que existe en la iglesia, dice el teólogo reformado Juan Bocs, un ministerio pastoral o episcopal al cual incumbe el oficio de la predicación de la Palabra y de la administración de los sacramentos, de la conducta del rebaño y: de la edificación de la casa de Dios, y que a ese ministerio se le ha dado la autoridad de la Palabra que dispensa, eso es innegable y es preciso admirar la profundidad con la que los textos del Vaticano II han puesto de relieve esta realidad» ${ }^{23}$.

Una vez dibujado el enfoque general, cuyas características positivas se han recogido, el Concilio limita el campo de su trabajo, declarando que use propone; ante la faz de todos, profesar y declarar la doctrina acerca de los obispos, -sucesores de los apóstoles, los cuales, junto con el sucesor de Pedro, Vicario de Cristo y cabeza visible de la iglesia, rigen la casa del Dios vivol' ${ }^{24}$.

El tema es apasionante desde dentro y hacia fuera. Desde el Vaticano I la iglesia católica estaba en deuda con los obispos. Se sabe que en la agenda de trabajo del Vaticano I se encontraba precisamente este tema. $Y$ cómo por circunstancias, en parte históricas y en parte extrañas, el tema quedó sin tratarse. El Vaticano I había dado la doctrina sobre el papa. Una doctrina que hoy llama la atención y produce extrañeza en muchos círculos cristianos. El papado, tal y como lo presenta el Vaticano I, podía convertirse en una monarquía absoluta, de no estar contrapesado por una enseñanza justa acerca del episcopado. La deuda estaba pendiente. El Vaticano II intenta saldarla.

Para conseguir esta meta, el Vaticano II desarrolla un esquema teológico, que parece tener estas líneas maestras. En el origen del ministerio aparece el Señor Jesús. El Concilio recoge sin más el hecho que refieren los evangelistas sobre la elección de los Doce (cf. Mc 3, 13-19; Mt 10, 1-42; Lc 6,13). El Concilio resalta que Jesús «instituyó a los apóstoles a modo de colegio, es decir, de grupo estable, y puso al frente de ellos a Pedro, elegido de entre ellos mismos (cf. Jn 21, 15-17) " ${ }^{25}$. A la elección sigue la misión, primero, a Israel; luego, a todas las gentes, con el encargo de predicar el Evangelio, de bautizar y hacer discípulos de Jesús en todo el mundo (cf. Mt 28, 16-20).

La misión, confiada por Cristo a los Once, trasciende el espacio y el tiempo en que su vida tiene que moverse. Con seguridad, este pensamiento no resultaba evidente en los primeros años de la iglesia. Los discípulos estaban

23. J. BOCS, Puntos de vista, 16.

24. LG. $18 \mathrm{~b}$.

25. LG. 19a. 
convencidos de que la vuelta del Señor era inmediata e iba a acontecer en el marco de su vida. De ahí, la urgencia y el apremio de la predicación. Pero los años pasaban. Los apóstoles envejecían. El Señor no volvía. Esta realidad palpable y cruda influyó en su cambio de pensamiento, sobre todo de aquellos que les siguieron en sus tareas. La iglesia tuvo que prepararse para una larga estancia en la tierra. Los apóstoles-tuvieron que pensar en el relevo, porque la misión debía continuar. Alguien tenía que tomar la antorcha y sucederles en la tarea (cf. LG. 20 a).

Para traducir esta realidad, la eclesiología tradicional católica romana había seguido el siguiente esquema: Cristo $\longrightarrow$ " Apóstoles $\longrightarrow$ " Obispos. Es un esquema lineal y simple, que no responde a la complejidad, novedad y evolución que del hecho ministerial nos da el Nuevo Testamentoy los datos históricos posteriores al Nuevo Testamento. ¿Sigue el Vaticano II este esquema? En el fondo, sí. No lo hace de una forma rígida. Pero no ha sido capaz de superar el peso de una tradición secular. «Entre los varios ministerios, que ya desde los primeros tiempos se ejercitan en la iglesia, según testimonio de la tradición, ocupa el primer lugar el oficio de aquellos que, constituidos en el episcopado, por una sucesión que surge desde el principio, conservan la sucesión de la semilla apostólica primera» ${ }^{26}$. Como se ve por el texto, el Concilio no se remonta hasta el Nuevo Testamento, sino que se queda en los estadios de una tradición primitiva. Lo cual le expone, como de hecho sucede, a limitar el punto de vista en una dirección concreta, en este caso la episcopal. Por eso, me parece que el Concilio ha caído en el inconveniente de traducir una realidad de hecho en una tesis de derecho. De ello nos da razón la siguiente doctrina: «Enseña, pues, este sagrado Sínodo que los obispos han sucedido por institución divina en lugar de los apóstoles como pastores de la iglesia, y quien a ellos escucha, a Cristo escucha, y quien los desprecia, a Cristo desprecia y al que lo envió (cf. Lc 10,16)») ${ }^{27}$.

Una vez que el Concilio expresa su postura frente al tema delicado de la sucesión episcopal (más adelante volveré sobre el tema), a renglón seguido se plantea la cuestión de la sacramentalidad del episcopado y se define sobre ella (cf. LG. 21c). Esta postura indudablemente simplificada suscita muchos interrogantes en el ambiente interconfesional. Puede ser un dato negativo a la hora de abrir camino hacia la meta de la unidad. Prescindo de hacer referencia a dichos inconvenientes por no entrar directamente en el tema que me he propuesto desarrollar.

Indiscutiblemente el logro más grande del Vaticano II por lo que respecta a los ministerios es la doctrina sobre la colegialidad de los obispos. Esta doctrina, y esto hay que reconocerlo, no es nueva. Estaba, tan solo, bastante olvidada en la eclesiología católica romana. La preeminencia que la figura del pa-

26. LG. 21a.

27. LG. 20c. 
pa había adquirido en la iglesia católica romana, sobre todo a partir de las enseñanzas del Vaticano I, había sumido a los obispos en una situación de inoperancia. Con frecuencia su labor pastoral quedaba reducida a seguir paso a paso las orientaciones que venían de Roma. La centralización romana era tal que los obispos veían reducido su horizonte de acción pastoral.

Una tal situación no.respondía ni a perspectivas bíblicas ni tampoco a presupuestos eclesiológicos. Tanto en la sagrada Escritura como en la eclesiología antigua estaba bien presente el principio de la colegialidad. Son ejemplos claros la constante actuación de Pedro recogida en los doce primeros capítulos de los Hechos. Pedro nunca obra solo. Y si, en alguna ocasión impulsado por una acción carismática, lo hace (cf. Hech 10,15S.), Pedro tendrá que rendir cuentas a la comunidad. (cf. Hech 11,1s.). La cumbre de este obrar colegial está en el llamado concilio de Jerusalén (cf. Hech 15,6s).

El mismo fenómeno aparece en el hecho eclesiológico de la ordenación episcopal. El obispo es el pastor de la grey que se le encomienda. Sin rebaño no puede haber pastor. Pero el obispo es también el instrumento de comunión con las otras iglesias locales. Para expresar tal comunión, ya, desde antiguo, apareció el hecho litúrgico de que el obispo fuera consagrado en presencia, al menos, de tres obispos. De este modo se expresaba la solidaridad de sú labor pastoral en la preocupación de todas las iglesias.

Como hechos cumbres de esta colegialidad, es decir, de que los obispos participan solidariamente en la solicitud por todas las iglesias, tenemos los concilios regionales, nacionales $y$, sobre todo, ecuménicos. En estos concilios, el obispo traspasa el límite de sus preocupaciones pastorales ordinarias, para situarse, colegialmente, en una dimensión parcial o totalmente universal.

A pesar de que la colegialidad, como se acaba de expresar, no es un hecho nuevo, sin embargo su doctrina, recogida y resaltada por el Vaticano II, ha producido un gran impacto. Esta doctrina ha abierto el camino para un amplio diálogo ecuménico respecto al tema de los ministerios. Pues ella ha barrido, en principio, con todas las suspicacias que una concepción piramidal de los ministerios había producido en otras confesiones cristianas. La colegialidad, al menos como punto de partida y como intuición, nivela el panorama y rebaja la eclesiología vertical a un nivel horizontal. Es verdad que resta aún perfilar teológicamente la figura del obispo de Roma dentro de la colegialidad. Pero también es verdad que el camino reencontrado de la colegialidad presenta unas perspectivas, de proporciones insospechadas, para la conquista de la unidad. Por ello hay que saludar con gozo y alegría esta doctrina del Vaticano II y verla como una de sus más grandes intuiciones.

En apoyo de lo que vengo diciendo, se me ocurre recoger algunos textos que presentan la colegialidad como nervio aglutinante de una eclesiología ecuménica. Sirvan, como telón de fondo, estas hermosísimas expresiones del papa Gregorio I, dirigidas al obispo de Alejandría, Eulogio: «Os ruego que no me habléis más de lo que yo he mandado, porque sé bien quién soy yo $y$ quiénes sois vosotros, los que en dignidad sois mis hermanos, $y$ en virtudes 
mis padres. Yo no mandé nada, sino que procuré manifestar lo que pareció conveniente... En vuestra carta me disteis aquel título de vanidad por el que me llamáis papa universal. Pido a vuestra santidad, para mí tan querida, que no lo hagáis más, pues vos quedáis privado de aquello que a mí me dáis más allá de lo que es razón. Porque yo no quiero medrar con títulos, sino con virtudes. Ni pienso que sea honor para mí aquello que redunda en menos honor para mis hermanos. Mi honor es el honor de la iglesia universal. Mi honor es el sólido vigor de mis hermanos. Entonces me siento verdaderamente honrado, cuando a nadie se le niega el honor que le es debido. Porque al llamarme vuestra santidad padre universal, parecéis negar que vos mismo sois también padre. No quiero nada de esto. Fuera toda palabra que hincha la vanidad y hiere la caridad ${ }^{28}$. Gregorio habla aquí el lenguaje de la mística. Sus palabras manifiestan un alto grado de virtud. Pero también es necesario reconocer que habla el lenguaje de la teología. Un lenguaje que nos dice bien alto qué piensa él de sus relaciones con los demás obispos y cuál es la conciencia de la iglesia primitiva sobre el tema. Sus palabras carecen de todo aquello que pueda significar un tono de superioridad en favor del obispo de Roma y expresan la igualdad radical que existe entre todos los obispos. Con lo cual Gregorio Magno se mantiene en la verdadera tradición de la iglesia primitiva.

De esta tradición se ha hecho portavoz cualificado la ortodoxia. Todos conocemos su postura radical $y$, hasta cierto punto, intransigente sobre el tema. Ello pudiera producir la impresión, a mi modo de ver equivocada, de tozudez irracional. Es posible que la postura de la ortodoxia se haya endurecido como consecuencia de ciertas situaciones históricas. Pero, en el fondo, responde a la tradición auténtica de la iglesia primitiva. Tal vez estas palabras suenen extrañas para los oídos católicos romanos. Pues en ellas se puede ver una negación del primado del obispo de Roma. No es así. Con ellas no se quiere negar el primado, sino tan solo matizar el sentido de dicho primado. El primado aparece en la tradición de la iglesia primitiva y se acepta por todas las iglesias cristianas, incluso la iglesia ortodoxa. Lo que no se acepta, y ahí está si responde o no a la auténtica tradición de la iglesia, es un modelo de primado que resulte una pieza extraña en el engranaje de la colegialidad. Por tanto la cuestión, como lo veremos más en detalles, se plantea así: no se rechaza el primado en sí, sino un cierto modelo de primado.

En este sentido, me parece oportuno recoger unas palabras del obispo ortodoxo Emiliano Timiadis. Dice así:

"La ortodoxia, fiel a la tradición antigua, permanece sinodal, colegial, episcopal y autocéfala. La eclesiología eucarística reposa sobre la interdependencia del cuerpo sacramental y del cuerpo eclesial de Cristo. En cualquier lugar en donde se parta el pan eucarístico allí está la iglesia de Cristo (cf. 1 Cor 10,17). El cuerpo de Cristo no puede estar dividido. La Iglesia local, que celebra el

28. Gregorio Magno a Eulogio, obispo de Alejandría: PL 77, 933. 
sacramento, es la iglesia en su plenitud: ella es, 'la iglesia que está en Corınto', como dice san Pablo para Corinto. La iglesia local también es autónoma; ella no es parte integrante de un conjunto que sería la iglesia universal» ${ }^{29}$.

Esta es, en verdad, la postura de un teólogo. Pero él refleja el sentir general de la ortodoxia, del que se puede ver un testimonio comunitario en la declaración del sínodo de Constantinopla de 1895. Este testimonio expresa las bases teológicas en que se apoya su enseñanza, por lo que tiene un valor extraordinario. "Que el obispo de Roma sea reconocido en un pie de igualdad con el obispo de Constantinopla y los obispos de otras iglesias; ningún canon conciliar, ningún Pastor hacen alusión al hecho de que el obispo de Roma era reconocido como jefe supremo de toda la iglesia, teniendo una jurisdicción universa/ sobre todos los obispos de iglesias independientes y autocéfalas, ya como sucesor del apóstol Pedro, ya como vicario de Cristo sobre la tierra» ${ }^{30}$.

La última confirmación de la posición ortodoxa procede de la boca del actual patriarca ecuménico de Constantinopla, Demetrios, en su respuesta a la delegación Vaticana del 30 de noviembre de 1973:

«Hablando de nuestras iglesias nosotros no desistimos de la doctrina eclesiológica sobre la iglesia una, santa, católica y apostólica; nosotros entendemos, de este modo, a las iglesias locales, respetada cada una en su jurisdicción... Estamos obligados a repetir y a señalar aún una vez más que en la cristiandad, ningún obispo posee ningún privilegio, divino o humano, sobre la iglesia una, santa, católica y apostólica de Cristo, sino que todos nosotros, sea en Roma, sea en esta villa de Constantinopla, sea en otra cualquier villa, - cualquiera que sea su posición en la jerarquía eclesiástica o en el mundo político- ejercemos nuestra carga episcopal en la colegialidad pura y simple, bajo un sólo pontífice supremo, que es la cabeza de la iglesia, nuestro Señor Jesucristo, y ello según el orden jerárquico aceptado desde siempre en la iglesia» ${ }^{31}$. Y añade, como base de un diálogo ecuménico en el futuro, dos condiciones indispensables: «primera, la autoridad suprema de la iglesia una, santa, católica y apostólica reside en el concilio ecuménico de la iglesia universal; segunda, ningún obispo de la iglesia universal tiene autoridad, privilegios o derechos acordados canónicamente sobre una jurisdicción eclesial, cualquiera que sea, sin el consentimiento canónico del interesado" ${ }^{32}$.

Los textos son elocuentes y claros. Expresan una postura decidida por parte de la ortodoxia. Postura de la que difílcilmente se alejará, puesto que la basa en una tradición constante. A primera vista parece que existe entre católicos romanos y ortodoxos un profundo bache, que va a resultar difícil llenar. Sin embargo, el puente, que puede unir las dos orillas, se encuentra en la co-

29. E. TIMIADIS, «Primado de Pedro y eclesiología ortodoxa»: Istina 4 (1978) 360-361.

30. E. TIMIADIS, Primado de Pedro, 363.

31. E. TIMIADIS, Primado de Pedro, 363.

32. E. TIMIADIS, Primado de Pedro, 363. 
legialidad. Una colegialidad que tenga verdadero contenido y no quede en simple nominalismo.

En la colegialidad, por su eco profundo en las iglesias, se puede y se debe encontrar el verdadero punto de apoyo para emprender y lograr tarea fecunda en el camino de la unidad. Las razones de esta afirmación se encuentran en la acogida favorable que en todas las otras confesiones cristianas ha tenido el tema de la colegialidad. De ellos son elocuente testimonio todos los documentos ecuménicos, elaborados en razón de los ministerios. No podía suceder de otra manera. Todos estos documentos se despojan, como primera medida, de posturas esenciales dogmáticas y juridicistas. Posturas que, por su intransigencia, no favorecen el diálogo ecuménico. Por contraposición, estos documentos se sitúan en terrenos particularmente bíblicos e históricos, muy propicios para dar con la vena flexible de la vida eclesial que corre bulliciosa sin someterse a fórmulas rígidas de pensamiento. El Evangelio es, antes que nada, anuncio de salvación para todos los hombres. Dios cumpie su promesa hecha a su pueblo y revela su amor salvador hacia el mundo en la vida, muerte, resurrección y segunda venida de Jesucristo. Proclamar este Evangelio es vital para la iglesia y constituye la misión a cumplir a lo largo de todos los siglos. En ella radica su razón de ser y la fuente de su vida. Y a ello debe contribuir todo lo que nazca en su interior. Las estructuras caen bajo esta ley universal. Están al servicio de la misión. Su valor y razón dependen de esa misma misión. Tienen, por tanto, un carácter eminentemente funcional. Carecen de un valor absoluto, de tal manera que su existencia depende primordialmente de la eficacia para la que están destinadas.

La colegialidad no es un fenómeno extraño al ser de la iglesia. Se enraíza en el sentido de comunión que es lo que constituye la vida de la iglesia en su sentido más profundo. Por su riqueza de contenido y por la revalorización que encarna del sentido de comunión en la iglesia y, en consecuencia, de la acción colegial, creo interesante recoger aquí el siguiente texto:

«Confesar a Cristo como Señor constituye el núcleo, el corazón de la fe cristiana. Dios le ha dado toda autoridad en el cielo y en la tierra. Como Señor de la iglesia, envía el Espíritu Santo para crear una comunión de hombres con Dios y de hombres entre sí. Desde la eternidad Dios se ha propuesto llevar esta Koinonía a su perfección. Si la iglesia existe, es para que contribuya a la plena realización de este plan divino, la cual ha de tener lugar cuando Dios sea todo en todos» ${ }^{33}$.

Como se ve, la acción solidaria y colegial es patrimonio irrenunciable de toda la iglesia. Si ésta tiene que servir a la construcción de la Koinonía frente al mundo, también tiene que hacerlo, y ello en primer lugar, en el interior de sí

33. COMISIÓN internacional anglicana-católica romana, Naturaleza, ejercicio e implicaciones de la autoridad en la Iglesia (Venecia 1976) núm. 1. 
misma. La iglesia, en verdad, sirve a la Koinonía. Pero es, antes que nada, Koinonia.

Esta realidad, por lógica interna, se transfiere a todos los miembros de la iglesia y, en particular, aquellos que ejercen un ministerio dentro de la iglesia. Se transfiere desde dentro y hacia fuera. Quienes ejercen el ministerio son Koinonía por ser iglesia. Tienen la misión de predicar la Koinonía a los hombres. La colegialidad, por tanto, no nace sólo de un hecho histórico, de que los Doce fueron instituidos por Jesús como colegio, sino que nace sobre todo del mismo ser interno de la iglesia. La colegialidad sitúa el ministerio en un horizonte en donde convergen y se proyectan las grandes luces que iluminan el misterio de la iglesia. Recuérdese la idea de Pablo acerca de la iglesia como cuerpo de Cristo. Idea precisamente que le sirve para enmarcar y potenciar el sentido de los dones del Espíritu en la iglesia (cf. 1 Cor 12,4s).

La colegialidad, al volver al sentido bíblico de los ministerios y a la praxis de la iglesia primitiva, supone un paso de gigante en el acercamiento entre todas las iglesias. La doctrina de la colegialidad es la superación, al menos parcial, de una eclesiología piramidal y monárquica. Con lo que se afirma que es la superación de la eclesiología tradicional católica romana. La colegialidad manifiesta y potencia el sentido comunitario en la acción eclesial. Por ello, constituye uno de los logros más grandes del Vaticano II en todos los frentes, particularmente en el ecumenismo.

«Esta declaración, dice Juan Bocs, (se refiere el $n .^{\circ} 22$ de la LG.) es de una importancia capital, porque ella afirma el carácter comunitario del gobierno de la iglesia. Sobre este punto nos encontramos en una perspectiva eclesiológica que ha sido constantemente subrayada por los reformadores. En efecto, si la iglesia es la asamblea de los que han sido reunidos por la fe en la comunidad de Cristo, el gobierno de la iglesia no puede ejercerse sino en la sumisión del pueblo entero a las directrices de su Señor. La doctrina del sacerdocio universal implica que la autoridad de la iglesia se ha de concebir ante todo como la obediencia del pueblo a su jefe supremo; el ejercicio de esta autoridad, si recurre necesariamente a órganos más restringidos, no podrá ser asumido más que por colegios que representen a la comunidad entera en la búsqueda de la voluntad del Señor y en la sumisión a esta voluntad») ${ }^{34}$.

Para terminar y redondear estas impresiones enormemente positivas sobre la colegialidad como paso de gigante en el camino del encuentro con las otras iglesias cristianas, cito unas palabras del grupo teológico luteranocatólico de Estados Unidos acerca del primado del papa:

«La responsabilidad colegial, en lo que se refiere a la unidad de la iglesia, tal como ha sido subrayada en el Vaticano $\mathbb{l}$, es de una gran importancia para defender los valores que una centralización excesiva tendía a ahogar. Ningu-

34. J. BOCS, Puntos de vista, 24. 
na persona, ningún estamento administrativo, a pesar de su dedicación, de su ciencia y de su experiencia, se encuentra en condiciones de captar toda la complejidad de situaciones en que se halla una iglesia extendida por todo el mundo, dentro de la cual hay comunidades que viven y dan testimonio en contextos completamente diferentes a lo largo de numerosos continentes y naciones. Los problemas urgentes que en semejantes circunstancias se dan, solamente pueden ser detectados por numerosos grupos y personas, y la capacidad necesaria para solucionar tales problemas sólo puede encontrarse con la aportación de muchos. El principio de la colegialidad interpela a todos los niveles de la iglesia a tomar parte en la preocupación y en la responsabilidad de dirección para la vida total de la iglesia» ${ }^{35}$.

Si la doctrina sobre la colegialidad constituye el centro alrededor del cual gira la doctrina del Vaticano II sobre los ministerios, existen también otros puntos que presentan un valor extraordinario en la conquista de la unidad. Precisamente por este matiz, y teniendo ante los ojos, por lo que mira este punto, las iglesia salidas de la reforma, es necesario no pasarlos por alto. Me refiero, en concreto, a la necesidad de predicar el Evangelio, que el Concilio Vaticano II coloca como tarea prioritaria de los obispos y de los presbíteros. «Entre los oficios principales de los obispos se destaca la predicación del Evangelio» ${ }^{36}$. "El pueblo de Dios se reúne, ante todo, por la palabra del Dios vivo, que con todo derecho hay que esperar de la boca de los sacerdotes. Pues como nadie puede salvarse si antes no cree, los presbíteros, como cooperadores de los obispos, tienen como obligación principal el anunciar a todos el Evangelio de Cristo, para constituir e incrementar el pueblo de Dios, cumpliendo el mandato del Señor: 'ld por todo el mundo y predicad el Evangelio a toda criatura' ${ }^{37}$. El valor de esta afirmación conciliar no radica en la novedad. Está en recordarlo, ya que se encontraba olvidado y descuidado. Uno de los motivos reales, constantemente alegado por los reformadores, en contra de una simplificada y lineal sucesión apostólica en favor de los obispos, fue precisamente el olvido de la predicación del Evangelio. Si no se predica el evangelio, y éste era, a su juicio, el fallo de los obispos de su tiempo, resulta incongruente reivindicar la permanencia en la sucesión apostólica. Los textos, sobre el particular, son crudos en su terminología, pero no cabe duda que nacen de un convencimiento profundo. Los reformadores están convencidos de que la Iglesia encuentra sólo su razón de ser en la medida en que cumple la misión de evangelizar. La predicación trae, como postulados necesarios, las otras tareas. Pero ella constituye, sin lugar a dudas, la tarea de las tareas. "¿Cómo invocarán a Aquel en quien no creyeron? Y ¿Cómo creerán si nada oyeron de Él? Y ¿Cómo oirán si nadie les predica? ¿Cómo predicarán si no

35. GRUPOS anglicano católico romano, «El Primado del Papa»: Seminarios 57-58 (1975) 497.

36. LG. 25a.

37. PO. $4 a$. 
fueren enviados? Según está escrito: ¡Cuán hermosos son los pies de los que anuncian el bien!» (Rom 10, 14-15). Los reformadores fueron especialmente sensibles a la necesidad de predicar el Evangelio. $Y$ alzaron su voz profética contra aquellos pastores que, olvidados de esta tarea primordial, se dedicaban a otros menesteres en la iglesia de Dios. Al obrar así se situaron en la auténtica tradición eclesial. Tradición recogida en este texto expresivo de Tomás de Aquino: «No creemos en la sucesión de los apóstoles y profetas, sino en la medida en que anuncian lo que éstos habían dejado escrito" ${ }^{38}$.

Tanto Lutero como Calvino, los dos grandes reformadorés, son categóricos y explícitos sobre el particular. Más polémico el primero que el segundo. No obstante, en los dos alienta el mismo soplo profundo.

«Si nuestros obispos, abades, etc., estuviesen de verdad en lugar de los apóstoles, tal como se glorían, se podría admitir, sin ningún género de duda, que podrían hacer lo que Timoteo, Tito; Pablo y Bernabé hicieron, al establecer sacerdotes, etc. Pero dado que están en lugar del diablo y son lobos que no enseñan ni dejan que se tolere el Evangelio, el cuidado de regular el ministerio de la predicación y la cura de almas les corresponde en medida tal mermada como a los turcos y judíos...

Puedes ver que nuestros obispos y eclesiásticos son ídolos y no obispos: abandonan el ministerio de la Palabra, que es el más digno y en el que debieran ocuparse, a los más humildes, es decir, a capellanes y mendicantes. $Y$ lo mismo hacen con ministerios de importancia como son el bautismo y la cura del almas. Mientras tanto, ellos se dedican a confirmar y a consagrar campanas, altares, iglesias. $Y$ a todo lo que no tiene nada de cristiano y episcopal y que se han inventado ellos mismos» ${ }^{39}$.

Con la misma firmeza, aunque con menos tinte polémico, se expresa Calvino.

"he ahi una ley inviolable que se impone a todos los que se dicen sucesores de los apóstoles, la cual deben observar a perpetuidad: Es la de predicar el evangelio y administrar los sacramentos. Por tanto, concluyo yo, que los que descuidan lo uno y lo otro falsamente pretenden estar en el estado apostóli$\cos { }^{40}$.

Por su condición de escritos confesionales Luteranos, tiene un valor extraordinario recoger aquí el pensamiento de la reunión de Schmalkalda sobre el tema que estoy tocando.

«Si los obispos lo fueran cie verdad y se decidiesen a atender a la iglesia y al evangelio, por motivos de caridad y unidad - pero no por una necesidad-,

38. TOMÁS de Aquino, De veritate, q. 14, a. 10, ad 11.

39. M. LUTLERO, Derecho de la comunidad a elegir sus predicadores; texto tomado de las Obras de Lutero. Ed. de Teófanes Egido (Salamanca 1977) 355.

40. J. CALVINO, Institutiones Christianae, IV , 3, 6. 
se les podría permitir que ordenasen y confirmasen a nosotros $y$ a nuestros predicadores, con tal de que prescindiesen de todas las apariencias y fantasmagorías de una pompa que nada tiene de cristiano. Pero no son obispos verdaderos ni desean serlo; mejor estaría decir que son señores y príncipes seculares, a quienes no interesa predicar, ni enseñar, ni bautizar, ni administrar la santa cena, ni ejercer obra ni ministerio de la iglesia; es más, persiguen y condenan a los que ejercen este ministerio por su vocación. Por eso, la iglesia no tiene que prescindir de sus ministros a causa de los obispos» ${ }^{41}$.

La situación, que denuncian al unísono Lutero y Calvino, situación indiscutiblemente real en la iglesia de su tiempo, tuvo y tiene repercusiones negativas para la unidad. Ella influyó de manera importante en la separación de las iglesias salidas de la reforma. $Y$ ella sigue influyendo en el mantenimiento de dicha separación. Varios teólogos Luteranos han tenido dudas acerca de la validez del ministerio católico romano, precisamente a causa de la falta de su compromiso hacia la predicación del Evangelio. Mientras estas dudas existan, constituirán siempre un obstáculo importante en el camino de la unidad. Por eso, el Vaticano II, al recordar, tanto a los obispos como a los presbíteros, la tarea prioritaria de predicar el Evangelio, elimina, en principio, un obstáculo serio en el camino hacia la unidad. El documento interconfesional de los Estados Unidos recoge, con agrado, esta enseñanza del Concilio.

«No existe base alguna en el libro de la Concordia para negar que los sacerdotes católicos romanos sean ministros competentes del Evangelio y de los sacramentos. Si bien es cierto que algunos Luteranos, en épocas anteriores, hayan dudado de que el ministerio de los clérigos católicos romanos sea realmente un ministerio del evangelio, el hecho de que el Vaticano II haya considerado la proclamación del Evangelio de Dios a todos lo hombres, 'como deber primordial' de los sacerdotes de la iglesia católica romana debiera disipar tales dudas" ${ }^{42}$.

La enseñanza del Vaticano II acerca de la predicación del Evangelio como tarea prioritaria del ministerio supera la visión tradicional de éste en la iglesia católica romana. Todos sabemos que el ministerio, dentro de la iglesia católica romana, se encontraba caracterizada, casi en exclusiva, de forma ritual. El sacerdote se ordena, ante todo, para celebrar la misa. Ésta era su tarea primordial y, en muchas ocasiones, única. Con lo cual, no sólo se mediatizaba su condición de ministro en la iglesia, sino que se viciaba, en parte, su mismo ministerio. De ahí la importancia de la doctrina conciliar al poner como tarea

41. Art/culos de Schmalkalda; texto tomado de las Obras de Lutero. Ed. de Teófanes Egido (Salamanca 1977) 355.

42. GRUPO teológico luterano-católico de Estados Unidos, Eucaristía y ministerios, 478. 
prioritaria del ministerio la predicación del Evangelio, en virtud de la cual queda superada la figura del sacerdote como hombre del culto.

B.- Sombras. Si intensas son las luces, como acaba de recogerse, intensas son también las sombras que se proyectan sobre el capítulo tercero de la Lumen Gentium. Comprensibles, en verdad, por un lado, resultan bastante inexplicables, por otro. Son comprensibles, en razón de las limitaciones a que está sometido todo concilio. Ningún concilio, y menos un concilio de la iglesia católica romana, en la que pesa siempre grandemente la tradición, comienza a partir de cero. Esto es normal. No se puede hacer tabla rasa de todo lo anterior. Pero hay grados y grados en el tema. Si no se puede hacer tabla rasa, sí hay que tener la valentía de prescindir de aquello que se ha convertido en un peso muerto; que se presenta como un obstáculo insalvable en el camino. A esto no llega el Concilio Vaticano II precisamente en el tema de los ministerios. $Y$ esto es lo inexplicable. El análisis que se va a hacer, creo que arrojará luz suficiente sobre el tema como para llegar a una explicación objetiva. En principio, digo que es inexplicable, si se tiene en cuenta la meta que se había propuesto el concilio. Esta meta es presentada en el proemio del decreto sobre el ecumenismo. Consiste en alcanzar la unidad entre todos los cristianos (cf. U.r. Proemio).

El concilio es convocado, entre otras cosas, con esa finalidad. Por tanto al concilio hay que exigirle conciencia clara de todos los obstáculos serios que se encuentran en el camino de dicha meta. Entre estos obstáculos está el problema de los ministerios. Tener conciencia clara de una problemática concreta supone saber distinguir entre elementos que pueden constituir unas coordenadas constantes, cuya pérdida desvirtuaría la misión de la iglesia, y elementos que pueden ser consecuencia de una idiosicrasia peculiar de pueblos y lugares y que son simplemente transitorios. Para conseguir esta discriminación, el Concilio debía haberse acercado al dato bíblico en una mayor amplitud y haber prescindido, en grado mucho mayor, de ciertas posturas confesionales. Me parece que el Concilio no ha logrado esta meta. $Y$ aquí radica el origen de esas sombras que se ciernen sobre el capítulo tercero de la Lumen Gentium.

Cuando uno lee, desde una perspectiva ecuménica y sin falsos criticismos, el capítulo tercero de la Lumen Gentium, se hace eco inmediatamente de un fenómeno extraño. Mientras los dos primeros capítulos utilizan un lenguaje que penetra profundamente por su sencillez evangélica y su tono carismático, el capítulo tercero cambia bruscamente de decoración. Hay un tono nuevo, que no puede por menos de extrañar. Usa un lenguaje pesado, cargado, en ocasiones, de un peso juridicista. Esta marcha aparece ya desde el mismo título "constitución jerárquica de la iglesia» y se proyecta a lo largo de todo este capítulo como una sombra que ennegrece el limpio horizonte de los 
anteriores. Ante esta anomalía uno, no sólo se extraña, sino que se pregunta el por qué. ¿Por qué este cambio de decoración? ¿Por qué un transfondo, un telón de fondo que llama profundamente la atención, extraña y da la impresión de ser un paso atrás en las esperanzas que se habían concebido?

La respuesta a estos interrogantes, enormemente válidos desde el punto de vista ecuménico, parece bastante clara. El Concilio ha tomado un punto de partida sumamente comprometido. De momento constato el hecho. Más adelante trataré de verlo en profundidad. El Concilio confiesa seguir los pasos del Vaticano I y propone; de nuevo, a la fe de los creyentes todo lo que este Concilio había definido acerca de la institución, perpetuidad, fuerza y razón del sagrado primado del romano pontífice y de su magisterio infalible (cf. LG. 18b). La figura, pues, del romano pontífice, delineada y acuñada por el Vaticano I, es una figura vertical en moldes jurídicos, eminentemente jurídicos. Por lo que resulta ya extraña en el contexto ideológico y en el lenguaje ordinariamente usado por el Vaticano II.

A lo largo de todo el capítulo y, sobre todo, cuando se habla de la colegialidad, aparece la figura del papa tal y como la plasma el Vaticano I. Y, lógicamente, aparece en una forma extraña y desarticulada de todo el engranaje en que se mueve la doctrina de la colegialidad. ¡Qué mal suena a oídos acostumbrados a tonos ecuménicos un lenguaje que habla de prerrogativas, poderes y dominios! Pues ese es el tono en que viḅra la figura del papa del Vaticano I y cuyas ondas repercuten en el Vaticano II. Como confirmación a lo que estoy diciendo, voy a recoger algunos párrafos del discurso de Pablo $\mathrm{VI}$ al comienzo de la sesión tercera del concilio y que influyeron definitivamente en la redacción del capítulo tercero de la Lumen Gentium.

«Este concilio, dice el papa, deberá confirmar lo ya proclamado por el Concilio Vaticano I, es decir, la doctrina sobre las prerrogativas del romano pontífice. Tendrá además, y como su fin principal; el de describir $y$ ensalzar las prerrogativas del episcopado... Si a Nos, como sucesor de Pedro, y, por tanto, en posesión de la plena potestad sobre la iglesia, compete el oficio de ser, aunque indigno, vuestra cabeza, esto no es para defraudaros la autoridad que os compete. Si nuestro oficio. apostólico nos obliga a poner reservas, a precisar términos, a prescribir formas, a ordenar modos en el ejercicio de la potestad episcopal, esto es - vosotros los sabéis - para el bien de la iglesia y para la unidad de la iglesia. $Y$ todo esto no sacrifica, antes al contrario, fortalece la autoridad episcopal, lo mismo si se la considera individual que colegialmenten ${ }^{43}$.

Después de esta impresión global, se puede abordar ya el tema, que me preocupa, de una forma directa. Recordaré brevemente algunas cosas que se dijeron en el apartado de las Luces, porque ellas ayudarán a captar mejor la

43. Pablo Pp. VI, Discurso a los Padres del Concilio al comienzo de la tercera Asamblea; texto tomado de J. L. MARTíN DESCALZO, Un periodista en el Concilio, 67. 
verdadera onda del problema, a tomar el pulso del mismo. Se hizo referencia al enorme cambio que suponía para la eclesiología católica romana la inversión de los capítulos segundo y tercero. En los primeros esquemas el capítulo tercero, dedicado a la jerarquía, aparecía antes del capítulo segundo, dedicado al pueblo de Dios. Con ello se demostraba que la eclesiología católica romana no había aún superado el marco de una Jerarcología. Todo este espectro desaparecía al lograr esa cambio de capítulos. La iglesia se presentaba, antes que nada, como pueblo de Dios. Desde esta perspectiva debían estudiarse todos los demás aspectos de la iglesia y, en concreto, la cuestión de la jerarquía. De este modo, se lograba engranar perfectamente con todas las demás visiones eclesiológicas, cuyas líneas fundamentales aparecen en los distintos documentos ecuménicos acerca del ministerio. Sirva, como ejemplo, este párrafo del documento de Accra:

«El ministerio ordenado debe ser entendido como un elemento de la comunidad. Para comprender el ministerio, es pues necesario partir de la naturaleza de la iglesia, comunidad de creyentes. La mayoría de las iglesias comparten hoy esta convición. Es por esto por lo que las consideraciones que siguen tienen como punto de partida a la comunidad cristiana; después, intentan definir la naturaleza y las funciones del ministerio ordenado a la luz de esta comunidad» 44

Se imponía, pur tanto, recordar estos pensamientos, para situarnos ya en el camino que ahora propiamente nos preocupa. Es decir, contemplar hasta qué punto el concilio se ha adaptado a ese punto de partida en el problema de los ministerios. $Y$ he aquí la primera impresión. El concilio parece olvidar este transfondo comunitario, desde el momento que se plantea el problema del ministerio especial. No basta, como lo hace, con hablar de la finalidad del ministerio, sino que es necesario, de forma ineludible, hacer referencia al soporte comunitario que le da sentido. El ministerio especial no puede ser comprendido en desconexión del ministerio de toda la iglesia. Cuando se hace esto, se corre el tremendo peligro de objetivar un ministerio especial por encima y. al margen de la comunidad. Con lo cual se cae fácilmente en el clericalismo, por una parte, y en la visión autoritaria, y no de servicio del ministerio, Por tanto, y habría que hablar mejor de certeza, que hay una desvinculación, un hiato, entre el capítulo segundo y el capítulo tercero. Esa desvinculación es una señal clara de que el concilio todavia se encuentra cogido en las redes de una eclesiología jerarcológica. He aquí una paradoja hasta cierto punto inexplicable, si se tiene en cuenta el punto de partida y las intenciones del concilio. ¿Por qué esta paradoja? Tal vez se puedan dar dos razones. Una de ellas es el. peso de tradición que carga sobre el concilio. Otra, las distintas presiones que, en oposición a la doctrina de la colegialidad, nacieron dentro del mismo

44. COMISIÓN de fe y constitución del C.E.I., Documento de Accra, 557. 
concilio y encontraron eco profundo en el mismo papa. El concilio, si quiso, no pudo librarse de esos dos inconvenientes y de ahí esa falta de lógica que supone el bache entre el capítulo segundo y el capitulo tercero.

Otro de los fallos, importantísimo desde el punto de vista ecuménico, es la ausencia de referencia a las epístolas genuinamente paulinas, cuando trata el problema de los ministerios. Se advierte con extrañeza que el concilio no alude a 1 Cor 12, 1s. Lo cual hace suponer una limitación en la visión del problema. Es sencillamente buscar un apoyo bíblico al tema de los ministerios, fijándose tan solo en escritos tardíos del Nuevo Testamento, en los que el ministerio ha conseguido ya una forma un tanto institucionalizada. Lo cual lleva consigo dar una serie de afirmaciones con carácter absoluto, cuando son consecuencia de un desarrollo completo. Yo llamo a esto el paso ilegítimo de un hecho a una tesis. Ello supone lo siguiente: Porque una cosa haya evolucionado en un sentido concreto, he aquí el hecho, no se puede afirmar que ello tenía que ser así y constituir una forma de principio invariable para el futuro, he aquí la tesis. Pongo un ejemplo que aclara esta idea precisamente en la línea de los ministerios. La evolución de los ministerios y la variedad de los mismos, reflejadas ya en el Nuevo Testamento, terminan, más allá del marco del Nuevo Testamento, en el obispo monárquico. Este es el hecho histórico, concreto. Pero este hecho no agota o no refleja totalmente la variedad de ministerios que atestigua, sobre todo, Pablo. Por consiguiente ese hecho no puede elevarse a la categoría de tesis y alcanzar un valor absoluto. De hecho, sucedió así. El obispo monárquico terminó por ser la pieza clave en la estructura ministerial de la iglesia. Teniendo en cuenta que, en la iglesia, acontece todo bajo la acción del Espíritu, ese hecho no puede tener simplemente un carácter sociológico, aunque indiscutiblemente el dato sociológico tuvo su influencia. Por tanto, se puede y se debe hablar de una actuación del Espíritu. Mas también se puede y se debe afirmar que el hecho sociológico tuvo su importancia. $Y$, desde luego, lo que no se puede ni se debe es eliminar la posibilidad de que la evolución se hubiera podido realizar en otro sentido. Precisamente el Espíritu es libertad, como se deduce claramente de la doctrina de Pablo acerca de los carismas. De hecho, según testimonio de Jerónimo en carta a Evangelo, la iglesia de Alejandría estaba gobernada por un presbiterio hasta muy entrado el siglo III.

Este es el motivo de la extrañeza que produce la doctrina conciliar acerca de los ministerios, prescindiendo de lo que dice Pablo sobre los carismas. Con lo cual, parece tomar ya una postura definida frente al problema limitándola en su alcance. Me atrevo a quitar el «parece» para dar una afirmación segura. Las palabras mismas del concilio lo indícan. Ellas expresan un esquema de pensamiento que no responde, en principio, a la doctrina de Pablo, y sí más bien, aunque simplificada, a la doctrina de los últimos escritores del Nuevo Testamento, en concreto de las cartas pastorales. Esto es situarse en una línea típicamente católica frente al problema de los ministerios. Por tanto, antes lo afirmaba, es tomar un punto de vista limitado en un problema que tiene 
horizontes más amplios. Según esto, no puede extrañar la declaración del concilio acerca de los obispos. "Este santo concilio, siguiendo las huellas del Vaticano I, enseña y declara con él que Jesucristo, eterno paistor, edificó la santa iglesia enviando a sus apóstoles como Él mismo había sido enviado por el Padre (cf. Jn 20,21). Y quiso que los sucesores de éstos, los obispos hasta la consumación de los siglos, fuesen los pastores de su iglesia» ${ }^{45}$.

Estas palabras reproducen en síntesis, un esquema lineal, que se puede dibujar de la siguiente forma: Cristo $\longrightarrow$ " Apóstoles $\longrightarrow$ " Obispos. Esquema, que ha estado muy presente a lo largo de la eclesiología católica romana, pero que hoy es, a todas luces, insuficiente, ya que parcializa la visión del problema. Los reduccionismos tienen siempre sus peligros. $Y$ el concilio no se escapa, en este caso, ni al reduccionismo ni a sus peligros. Congar afirma al respecto:

«Digamos, abreviadamente, que Jesús ha instituido una comunidad por entero santa, sacerdotal, profética, misionera, apostólica que, tiene en su seno, ministerios: Unos libremente suscitados por el Espíritu, otros, religados por la imposición de las manos a la institución y a la misión de los Doce. Habría que sustituir el esquema lineal por un esquema donde la comunidad apareciese como realidad envolvente, en cuyo interior, los ministerios, incluso los ministerios instituidos y sacramentales, se situaran como servicios de eso mismo que la comunidad está llamada a ser y realizar» ${ }^{46}$.

Tanto las palabras del concilio, como el esquema de base que las soporta, simplifican profundamente el problema de los ministerios y lo colocan en una situación incómoda para encontrar una salida adecuada. Es verdad que las cosas no acontecen sin razones. Por eso la postura del concilio tiene sus motivos. Responde a una constante muy clásica dentro de la eclesiología romana católica. Una constante que, hasta cierto punto, la ha enfrentado con la eclesiología de las iglesias salidas de la reforma. Me estoy refiriendo a la insistencia con que se ha tratado de poner de relieve el carácter cristológico del ministerio $y$, también, a las consecuencias que de ahí se han derivado. Uno y otras tienen matizaciones precisas. Es decir que, dentro de su contenido objetivo y verdadero, admiten precisiones, sin las cuales se desvirtúa su veracidad. En efecto, el ministerio tiene que vincularse, de alguna manera, a Cristo, es decir, al Jesús histórico. Esto se reconoce universalmente en ambientes ecuménicos. «No podemos hablar del ministerio de la iglesia y en la iglesia sin hablar primero del misterio del mismo Jesucristo ${ }^{47}$. Pero el problema se plantea a la hora de valorar este carácter cristológico y en el momento de sacar las consecuencias que de él se derivan. Aquí es donde puede estar, y de hecho está, la fuente de discrepancias. En la eclesiología católica romana ese

45. LG. $18 b$.

46. Y. M. CONGAR, Ministerios y comunión eclesial, 20-21.

47. GRUPO de DOMBES, Para una reconciliación de los ministerios, 536. 
carácter cristológico se interpreta como una institución divina. Se impone, por, consiguiente, como ley inexorable. Traducido esto a términos concretos supone lo siguiente: Jesús manda a los Doce que establezcan obispos en las iglesias y esta voluntad del Señor se constituye en imperativo insoslayable. Es decir, Jesús impone, ya desde su vida terrena, una estructura ministerial concreta, cuya línea maestra arranca de Jesús y llega hasta los obispos pasando por los Doce. Así aparecen las cosas en el texto antes citado del Vaticano II.

Las preguntas surgen de inmediato: ¿son así las cosas o no? El carácter cristológico del ministerio ¿lleva necesariamente a esos resultados? La iglesia, comunidad escatológica, ¿carece de la libertad necesaria para organizar, bajo la acción del Espíritu, los servicios que respondan mejor a las necesidades históricas en que se desarrolla? He aquí las preguntas, cuya respuesta no se puede formular en razón de presupuestos dogmáticos.

Como primera medida, hay que reconocer que las cosas no son así. El carácter cristológico del ministerio, acuñado como imperativo insoslayable, no responde ni a los datos del Nuevo Testamente ni a la evolución a que están sometidos los ministerios principalmente en los tres primeros siglos. Si Jesús hubiera impuesto una forma concreta de ministerio, los apóstoles, siempre dóciles a su voluntad, hubieran organizado las iglesias teniendo en cuenta la voluntad de su maestro, por tanto de una manera uniforme. Más ello no sucede así. En la organización de las iglesias primitivas aparece, según testimonios del Nuevo Testamento, pluralidad de estructuras, que responden a áreas territoriales en las que nace la iglesia. En las iglesias, bajo influencia judía, se presenta muy pronto el presbiterio como estructura básica dirigente. En las iglesias helenistas aparecen los epíscopos y los diáconos. No hay que olvidar las iglesias paulinas, ejemplo cumbre Corinto, donde la organización ministerial tiene un carácter predominantemente carismático, sin que ello suponga enfrentar carisma a institución, lo que conduciría a caer en un anacronismo.

En virtud, pues, de los datos neotestamentarios, el carácter cristológico del ministerio hay que entenderlo de forma particular $y$, en concreto, de una manera muy general. Me atrevo a calificarlo de englobante. Es decir, Jesús no instituye ministerios concretos. Envía a los Doce, con los mismos poderes que el Padre le ha enviado (cf. Jn 20,21) y aquéllos que son, en expresión del decreto Ad Gentes, "gérmenes del nuevo Israel y al mismo tiempo origen de la sagrada jerarquía» ${ }^{48}$ dotan a la iglesia, bajo la acción del Espíritu Santo, de los ministerios que la capacitan para cumplir su misión en el mundo. Así se mantiene la dialéctica, tan necesaria, entre aspecto cristológico $\dot{y}$ aspecto pneumatológico, a fin de evitar la esclerosis del ministerio, por un lado, y el ilusionismo, por otro. Lo primero amenaza constantemente a la visión católica del ministerio, por prescindir de manera casi absoluta del ministerio profético, lugar primordial de la acción del Espíritu. I_o segundo, a la visión protestante,

48. A.G. 5a. 
por prescindir, con más intensidad de la debida, de la conexión que existe entre ministerios eclesiales y ministerio de Jesús. Una dialéctica sana entre ambos polos constituye el punto de convergencia de las dos tendencias teológicas, a la hora de interpretar los datos del Nuevo Testamento sobre el ministerio. De ello se hace eco el documento de Accra:

«- La forma que tome el ministerio ordenado dentro de una tradición eclesial dada es debida a la interacción de estos tres elementos:

- La donación del mandato por Cristo -y la recepción del Espíritu Santo.

- La evolución de las estructuras de la sociedad.

- Las respuestas de la iglesia, conducida por el Espíritu, a la evolución de estas estructuras dentro del entorno social» ${ }^{49}$.

Este esquema recoge perfectamente la trayectoria del ministerio' en el Nuevo Testamento $y$, al mismo tiempo, expresa las condiciones y motivos que pueden empujar una legítima transformación o evolución. Por el contrario, la fórmula del Vaticano II, por ser reduccionista, se queda muy corta, tanto desde el punto de vista teológico como desde el punto de vista ecuménico. Tal como está expresada encuentra graves reparos en particular en las iglesias de la reforma que han prescindido del episcopado.

Este mismo reduccionismo aparece también en el tema, crucial para el ecumenismo, de la sucesión apostólica. No puede suceder de otra manera, supuesto el punto de vista adoptado por el concilio. Y eso que el Concilio flexibiliza la fórmula, cuando afirma: «Entre los varios ministerios que ya, desde los primeros tiempos, se ejercitan en la iglesia, según testimonio de la tradicción, ocupa el primer lugar el oficio de aquellos que, constituidos en el episcopado, por una sucesión que surge, desde el principio, conservan la sucesión de la semilla apostólica» ${ }^{50}$. En efecto, el concilio no sólo no se atreve a llegar hasta los umbrales del Nuevo Testamento, para proponer la doctrina de la sucesión apostólica por parte de los obispos, sino que reconoce también variedad de ministerios. Este último punto resulta interesante, aunque no suficiente sin más. El concilio tenía que haber seguido caminando por este sendero y tomar conciencia de que la sucesión no sólo afecta a los obispos, sino también a los otros ministerios. Incluso, y aquí está el punto de partida, la sucesión afecta, en primer término, a toda la iglesia. La iglesia se confiesa, en el credo, apostólica. $Y$ esa apostolicidad invade en todos los frentes a todo lo que en ella acontece. Pero el concilio se centra, como consecuencia de una visión reduccionista, en los obispos. Para ello, recoge una cita de Ireneo, y afirma: «Así, según atestigua Ireneo, por medio de aquellos que fueron establecidos por los apóstoles como obispos y como sucesores suyos hasta nosotros se pregona y se conserva la tradición apostólica en el mundo» ${ }^{51}$.

49. COMISIÓN de fe y constitución del C.E.I., Documento de Accra, 562.

50. LG. $20 \mathrm{~b}$.

51. LG. 20b. 
Después de los presupuestos reduccionistas, a que antes se ha hecho referencia, es fácil ya explicarse esta declaración solemne: «Enseña, pues, este sagrado sínodo que los obispos han sucedido por institución divina en lugar de los apóstoles, como pastores de la iglesian ${ }^{52}$.

Nos encontramos definitivamente en una línea ministerial concreta que es la episcopal. Dando un paso más, nos encontramos también en una eclesiología que no ha superado del todo el carácter excesivo de jerarcología. ¿Qué función puede desempeñar, función activa, pueblo de Dios frente a su fe en una perspectiva como la que aquí se presenta? Difícilmente se puede arbitrar otra función que la de obedecer fidelísimamente a las directrices de sus maestros y pastores (Cf. LG. 12a). Es decir, una función eminentemente pasiva. Choca profundamente todo esto con la declaración de los patriarcas orientales en respuesta a la encíclica «In suprema Apostoli Petri sede» de Pío IX;

«Entre nosotros ni los patriarcas ni los sínodos jamás han podido introducir novedades, ya que entre nosotros el guardián de la fe es el mismo cuerpo de la iglesia, es decir, el pueblo mismo, que quiere que su fe permanezca siempre inmutable» ${ }^{53}$.

Choca también, al menos a primera vista, con la postura que el concilio había tomado en el capitulo segundo. "La universalidad de los fieles que tienen la unción del Santo (cf. 1 Jn 2,20 y 27) no puede fallar en su creencia, y ejerce ésta su peculiar propiedad mediante el sentido sobrenatural de la fe de todo el pueblo de Dios, cuando 'desde el obispo hasta los últimos fieles seglares' (S. Agustín, De Praedo. Sanct., 14,27; P.L. 44,980) manifiesta el asentimiento universal en las cosas de fe y de costumbres») ${ }^{54}$. $Y$ ahora, cuando tiene que seguir en la misma dirección al hablar de los ministerios, el concilio realiza un corte extraño y se expone a caer en las redes peligrosas del clericalismo.

Para evitar estos inconvenientes gravísimos, hacia adentro y hacia afuera, el camino estaba trazado en el capítulo segundo. Partiendo de la iglesia como pueblo de Dios, la problemática de los ministerios y, en concreto, el tema de la sucesión apostólica ministerial encuentra una lógica convincente. No hay extorsiones ni desvíos. Toda la iglesia, como se confiesa en el símbolo, es apostólica. Toda la iglesia sucede a los apóstoles en lo que estos son objeto de sucesión. La iglesia, como tal, es la depositaria y la guardiana de la auténtica tradición apostólica. Sobre ella, como comunidad reconciliada y reconciliadora, gravita la obligación de transmitir dentro y fuera el mensaje apostólico de la salvación. En la fidelidad a este mensaje se encuentra primordialmente su apelativo de apostólica. Véase el nervio teológico y la calidad ecuménica de las afirmaciones del Grupo de Dombes:

\footnotetext{
52. LG. 20b.

53. Diálogo ecuménico, tomo 11 (1976) núms. 41-42, 132.

54. LG. 12a.
} 
"La apostolicidad de la iglesia se fundamenta en la fidelidad de Cristo a su promesa de estar todos los días con los suyos y en la presencia de acción del Espíritu Santo, quien sin cesar la edifica. Hay, pues, sucesión apostólica de toda la iglesia... En el seno de esta sucesión apostólica, Cristo, para atestiguar su iniciativa de gracia, garantizar la trascendencia del mensaje evangélico y asegurar el cumplimiento de la misión eclesiástica, ha enviado a los apóstoles como sus embajadores, gracias al don del Espíritu. Después de los apóstoles, el ministerio apostólico se continúa siempre en la iglesia sobre el cimiento que ellos constituyen, y debe permanecer plenamente fiel al mensaje transmitido por ellos. Este ministerio, don de Dios para el servicio de toda la iglesia, pertenece a la estructura de ella. Hay, sucesión apostólica en el ministerio instituido por el Señor» ${ }^{55}$.

Vista así la apostolicidad, en sus dos aspectos indisociables, no hay dificultad alguna para llegar a un consenso intereclesial. Los católicos romanos superarían el marco simplista y reducido de una concepción meramente lineal de la sucesión apostólica y las iglesias, salidas de la reforma, revalorizarían un tanto los ministerios, como algo que pertenece no sólo al bene esse de la iglesia, sino al esse de la iglesia. En esta perspectiva queda también superado el dilema al que hace referencia K. L. Schmidt, cuando escribe:

«Tenemos que resignarnos a admitir que ningún entendimiento es aquí posible entre la iglesia católica, sea romana, vétero-católica u ortodoxa-oriental, por un lado, y las iglesias de la reforma, por otro. La iglesia 'católica' hace derivar su autoridad de la afirmación en que está en posesión de un ministerio no solamente instituido por Jesucristo, sino que se ha transmitido por el camino, querido por él mismo de la sucesión apostólica... El pastor, el predicador evangélico actúa en el nombre de la iglesia, que le da el mandato de administrar lo que ella misma ha recibido de parte de Dios para administrar» ${ }^{56}$.

Nótese la fecha de este juicio, fecha ya un tanto lejana, y se advertirá inmediatamente que esta apreciación está superada del todo, como consecuencia de las conquistas eclesiológicas. Precisamente el punto de convergencia y de apoyo para lograr esa superación se encuentra en la primacía de la iglesia como pueblo de Dios a quien se confía, justamente por Cristo, la misión de predicar el Evangelio y se le concede, bajo la acción del Espíritu, todo lo necesario para llevar a cabo dicha misión. Según este modelo todo se remonta a Cristo que, por su Espíritu, se constituye en la fuente de vida para la iglesia. Lo que acontece en la iglesia se origina en Cristo y se potencia bajo el soplo vivificador del Espíritu. El pastor evangélico que, según Schmidt, actúa en el «nombre de la iglesia», actúa también en el «nombre de Cristo». Y el ministro

55. GRUPO de DOMBES, Para una reconciliación de los ministerios, 537.

56. K. L. SCHMIDT, "Ẹl ministerio y los misterios en la Iglesia del Nuevo Testamento»: Rev. Hist. Phil. Rel. 17 (1937) 315. 
católico que obra, en primer plano, como delegado de Cristo, en el nombre de Cristo, actúa también en el nombre de la iglesia. Todo ministerio pues, dentro de la iglesia encuentra su raíz en el ministerio o misión de la iglesia y, a través de ésta, en el ministerio de Cristo. Por tanto, la presentación que hace el Vaticano II de la sucesión apostólica es bastante limitada. Prescinde, en la práctica, del enlace, absolutamente necesario, entre Jesús y los ministerios que es la iglesia como pueblo de Dios. No puede constituir, de suyo, un paso decididamente adelante en el camino de la unidad. Esta enseñanza tiene que matizarse mucho más a través de dos movimientos. Un movimiento de despojo, abandonando posturas ya viejas, para perder derechos y poderes adquiridos ilegítimamente. $Y$ un movimiento de ampliación de óptica asumiendo en profundidad los datos neotestamentarios e históricos acerca del ministerio.

No quiero terminar estas impresiones, sin recoger aquí un testimonio cualificado, que, por otra parte, matiza muy bien la densidad de problemática que hay en el tema de la sucesión apostólica a través de los obispos:

«El término mismo de sucesión apostólica, dice Juan Bocs, se presta a equívocos; en efecto, nadie en la iglesia sucede a los apóstoles en lo que es el aspecto central, decisivo y único de su cargo, y que consiste en el hecho de que son testigos de la resurrección del Señor y fundamento de la iglesia. Sobre este punto, por lo demás, el acuerdo es general; la teología católica romana reconoce que hay en el cargo apostólico elementos intransmisibles. No se puede hablar de sucesión apostólica más que en lo concerniente a la misión de anunciar la palabra de Dios hasta los confines de la tierra, de apacentar y de edificar la iglesia; en ese sentido hay que hablar ciertamente de sucesión, pero con la conciencia del sentido restringido del término.

Además, si el testimonio apostólico ha sido confiado al pueblo de Dios en su totalidad, es la iglesia entera en primer lugar la portadora de la sucesión. Tampoco aquí el catolicismo romano formularía necesariamente objeciones a esta tesis, aunque la Lumen Gentium no alude explícitamente a ello" ${ }^{57}$.

Todos los inconvenientes, calificados aquí de reduccionistas, que aparecen en la doctrina del Vaticano II acerca de los ministerios, convergen, reforzados, en el ministerio cualificado del papado. Todos nosotros conocemos cómo la figura del papado constituye uno de los obstáculos más graves en el camino de la unidad. Desde esta perspectiva concreta, la iglesia católica romana se halla enfrentada, suavícese el término todo lo posible, con todas las otras grandes confesiones cristianas. Si en la doctrina del ministerio en general existen dos grandes bloques, el católico ( = iglesia católica romana, iglesia ortodoxa, iglesia anglicana, iglesia vétero-católica) y el protestante (=iglesias salidas de la reforma), en el tema concreto del papado la iglesia católica romana queda sola, enfrentada a todas las demás iglesias cristianas. El dato puede ser simple e insignificante para muchos. Si ella tiene la verdad, ¿Qué importa

57. J. BOCS, Puntos de vista, 33. 
que las otras confesiones cristianas no la acepten? Este modo de pensar es simplista. Está expuesto a profundas inexactitudes y no responde a la veracidad de los hechos. Es necesario imponerse la tarea de estudiar profundamente el tema y ver hasta qué punto la doctrina del papado, tal y como la presenta la iglesia católica romana, responde tanto a la veracidad del dato revelado como a la veracidad del dato histórico. La iglesia católica romana no puede soslayar el tema ni encerrarse en un dogmatismo a ultranza para defender su postura tradicional. Tiene que ser muy sensible a este problema, puesto que él se interpone como uno de los obstáculos mayores, tal vez el mayor, en la i ınión de las otras iglesias cristianas con ella misma: Es pueril pensar que en este hecho no existen razones de peso por parte de las otras confesiones cristianas. Es ilógico, sin más, creer que todas las otras iglesias cristianas están en el error, al paso que la iglesia católica romana se encuentra llana y simplemente en la verdad cristiana.

¿Se cuestiona con ello el papado? No y sí. No se cuestiona el papado como tal. Sí se cuestiona la imagen que la iglesia católica romana presenta del papado. Esta imagen constituye hoy por hoy un obstáculo insalvable en el camino de la unidad. De esa unidad que Cristo ha pedido y exigido para aquellos que creen en Él (cf. Jn 17,21). Esta voluntad del Señor entraña una tremenda responsabilidad para todas las iglesias cristianas, en particular para la iglesia católica romana. Como bloque mayoritario cristiano, tiene adquirida la obligación frente a los otros hermanos, de dar una respuesta que satisfaga los interrogantes de las otras iglesias.

La respuesta, en efecto, está dada. El concilio Vaticano I ha dicho expresamente y de forma solemne qué piensa la iglesia católica romana sobre el papado: A pesar de todo, esta respuesta, no sólo no satisface a las otras iglesias cristianas, sino que se constituye el nuevo motivo para permanecer separadas de la iglesia romana católica. ¿Por qué? ¿Por qué esta postura de las demás confesiones cristianas? ¿Rechazan el primado sin más? 0 tan sólo ¿rechazan una forma concreta, en este caso, la acuñada por la iglesia romana católica en el Vaticano I? La respuesta a estos interrogäntes se encuentran en estas palabras de A. Schmemann, teólogo ortodoxo: «El error eclesiológico de Roma consiste no tanto en la afirmación de sú primado, sino en el hecho de que ella identifica este primado con el poder supremo, haciendo del obispo de Roma un principio, una raíz y un origen de la unidad de la iglesia. Pero este error y esta alteración del dogma eclesiológico no deben conducirnos a negar puramente el hecho mismo del primado, sino por el contrario deben incitarnos a reflexionar más profundamente en su sentiфo ortodoxo" ${ }^{58}$. El camino a seguir está perfectamente trazado. No hay que negar el hecho, sino reflexionar profundamente sobre él para encontrarle su medida adecuada. Esta medida adecuada parece estar ausente, no importa por qué razones, del texto del Vaticano l:

58. A. SCHMEMÁNN, Primado dé Pedro en la Iglesia ortodoxa (Niestlé 1960) 141. 
"La dificultad primera e inmediata para la comprensión del servicio-de-Pedro está constituida por las expresiones del Vaticano I acerca del 'primado universal de jurisdicción' en la iglesia. El vocabulario que aqui se utiliza es crudo: 'la autoridad plena, suprema, de jurusdicción sobre toda la iglesia; no' sólo en las cosas de fe y de costumbres, sino también en lo que pertenece a la disciplina y a la dirección de la iglesia, sobre todos y cada uno de los pastores y de los fieles'” 59 .

$Y$, como remate, un texto elaborado en ambiente ecuménico:

"La interpretación teológica de esta primacía y la estructura administrativa a través de la cual se ha venido ejerciendo, ha variado considerablemente con el correr de los tiempos. Ni la teoría ni la práctica, sin embargo, han reflejado siempre estos ideales en toda su perfección. Repetidas veces la Sede de Roma desempeñó funciones que no estaban necesariamente relacionadas con el primado; la conducta del que ocupaba esta Sede no fue siempre digna del que desempeñaba este oficio; a veces la imagen del oficio mismo ha sido obscurecida con falsas interpretaciones. $Y$, a veces, finalmente, presiones externas han hecho su propio ejercicio casi imposible. A pesar de todo, la primacía del obispo de Roma, rectamente entendida, no mira sino a guardar y a promover la fidelidad de todas las iglesias de Cristo y la mutua fidelidad de unas a otras. Comunión con el obispo de Roma se considera como una salvaguardia de la catolicidad de cada iglesia local, y como potestativo de comunión entre todas las iglesias»" ${ }^{60}$.

Todos los textos citados expresan claramente un hecho. No se cuestiona el primado como tal. Lo que se cuestiona es su imagen tal y como se encuentra acuñada hoy en la doctrina de la iglesia católica romana. Se acepta un primado que, reflejo del servicio de Pedro, sirva a la unidad y a la comunión que tiene que existir entre todas las iglesias locales. Se rechaza el trasvase del servicio de Pedro a un papado de carácter eminentemente jurídico. El nudo, pues, de la cuestión está aquí.

Pesa sobre la iglesia católica romana la responsabilidad ineludible de hacer una reinterpretación de la figura del papado. $Y$ digo pesa, porque esta reinterpretación aún no está hecha. Seguramente esta labor no la puede realizar en solitario. Tiene que llevarla a cabo en comunión. Para lo cual se necesita abrir un diálogo abierto, sin temores ni suspicacias, con las demás iglesias cristianas.

El Concilio Vaticano II tuvo la gran oportunidad de dar un paso de gigante en este sentido, pero, por razones que no es necesario recoger aquí, se quedó muy corto y prácticamente renunció a realizar una reinterpretación de la figura del papa. Es verdad que sitúa la cuestión del primado en una nueva luz. Y ello

59. H. StITNIMANN, Papado y servicio de Pedro. Observaciones criticas (Fannkfurt am Main 1975) 28.

60. SECRETARIADO de la C.E. de relaciones interconfesionales. Autoridad de la /glesia. Declaración conjunta anglicano-romano, núm 12d. 
es recibido con agrado en ambientes ecuménicos. La colegialidad de los obispos puede servir de contrapeso a una figura papal dibujada con trazos monárquicos: $Y$ digo "puede» porque, en la práctica, resultará sumamente difícil compaginar figura del papa $y$ colegialidad. $Y$ esta dificultad radica precisamente en la ausencia de reinterpretación a la que antes me he referido. Por tanto, y en síntesis, hay que reconocer que el Vaticano II soslaya esta cuestión, al afirmar que «esta doctrina de la institución, perpetuidad, fuerza y razón de ser del sacro primado del romano pontífice y de su magisterio infalible, el santo concilio la propone nuevamente como objeto firme de fe a todos los fieles $y$, prosiguiendo dentro de la misma línea, se propone, ante la faz de todos, profesar y declarar la doctrina acerca de los obispos, sucesores de los apóstoles, los cuales, junto con el sucesor de Pedro, vicario de Cristo y cabeza visible de toda la iglesia, rigen la casa de Dios vivo» ${ }^{61}$.

Esta determinación del concilio extraña profundamente. Extraña, en primer lugar, porque no parece coherente con el propósito que había declarado prioritario: promover la restauración de la unidad entre todos los cristianos (cf. U. R. 1). Si éstas son su intención y finalidad, el concilio tenía que haber tómado conciencia de que la doctrina acerca del primado constituye uno de los obstáculos más serios en la restauración de la unidad de los cristianos. En fidelidad al propósito que él mismo expresa, se imponía una reinterpretación a fondo de la doctrina del Vaticano I, para conseguir una imagen más evangélica del primado $y$, de este modo, presentarla con posibilidades más grandes de acogida por parte de las otras confesiones cristianas. No lo hizo así. Seguramente existieron razones de muy diversa categoria, incluso algunas inexplicables desde el punto de vista evangélico. Ellas, en parte, afloran tanto en el discurso de Pablo VI, al comienzo de la tercera sesión del concilio, como en la nota explicativa, que se añadió al final de la constitución dogmática sobre la iglesia, para interpretar rectamente la doctrina de la colegialidad (cf. Documentos del Concilio, BAC. Madrid, 1965, pág. 119).

Se da aún otra anomalía. Extraña, en segundo lugar, cómo el concilio puede elaborar una doctrina de la colegialidad episcopal y dejar intacta la figura del papa. Es verdad que el Concilio intenta siempre presentar primado y colegio episcopal en perfecta armonía. Pero esta armonía parece más un arreglo teórico que una posibilidad real. Muy acertadas son, al respecto las observaciones de Juan Bocs:

"La cuestión está en saber en qué medida un primado definido en términos tan rigurosos no contiene en germen la negación del ejercicio de la colegialidad. Si el papa tiene verdaderamente en la iglesia el poder pleno, supremo $y$ universal, que puede ejercer siempre libremente, ¿no será posible por lo menos, en principio, poner en duda la autoridad del concilio?; tanto más cuanto

61. LG. $18 \mathrm{~b}$. 
que el concilio habla del papa como de la cabeza visible de la iglesia o como de la cabeza de la iglesia visible. Pero zno es colegial toda la estructura de la iglesia precisamente porque la comunidad cristiana no podría tener más cabeza que a Jesucristo mismo presente y operante alli donde dos o tres están reunidos en su nombre? Es importante darse cuenta de que no es el primado, en cuanto tal, lo que se pone en discusión en la doctrina de los reformadores...

La dialéctica de los poderes del papa y del concilio, tal y como aparece en el texto de la constitución, es una dialéctica en ruptura de equilibrio y va en detrimento, a los ojos de las iglesias de la reforma, de un dato eclesiológico fundamental» ${ }^{62}$.

En razón, pues, de estos datos, la enseñanza del Vaticano II acerca del ministerio papal está afectada de profundas lagunas, tanto desde el punto de vista teológico como desde el punto de vista ecuménico. El concilio, por las nuevas perspectivas eclesiológicas adoptadas (fundamentalmente la revalorización de la iglesia como pueblo de Dios, la colegialidad y la preocupación ecuménica), ni debía ni tenía que haber soslayado la reinterpretación de la doctrina del Vaticano I sobre el papado. Era, en verdad, una tarea delicada, por entrar en juego, nada menos y nada más que el magisterio de la iglesia. Mas ello no debe impedir plantearse serios interrogantes. ¿Hasta qué punto el Vaticano I recoge, en su formulación del papado, tanto el mensaje bíblico como la tradición de la primitiva iglesia? y, dado que el Vaticano I, hay que reconocerlo con libertad, ha sido desafortunado en su formulación de la doctrina del primado, no quedaba otro camino viable que haber emprendido la tarea de la reinterpretación. Se ha dicho, y lo repito ahora, que un primado, acuñado en términos del Vaticano I, y es la imagen única que existe en la iglesia católica romana, constituye un impedimento serio, desde la perspectiva de los ministerios, para el logro de la unidad. Desde esta perspectiva causa profundo dolor escuchar expresiones como las que contiene el discurso de Pablo $\mathrm{VI}$ al comienzo de la tercera asamblea del concilio. El papa habla de «prerrogativas» del papado y también de "prerrogativas» del episcopado. Me parece que este lenguaje no responde a una orientación eminentemente bíblica. Comprendo que en todo esto exista tan sólo un tono de sensibilidad. Pero a mí me resulta tremendamente cuestionable, cuando comparo esas expresiones con el lenguaje de la Biblia. ¿Cómo se puede hablar de prerrogativas o de derechos, cuando, a lo largo de todo el Nuevo Testamento, se presenta siempre cualquier actividad en la iglesia, como "servicio»? La única prerrogativa, si se puede hablar así, del servidor es servir. $Y$ en este caso no es prerrogativa. Es simplemente obligación. De ahí, las expresiones bíblicas: "Cualquiera que quiere hacerse grande entre vosotros, será vuestro servidor; y el que quiere ser entre vosotros el primero, será vuestro siervo; así como el hijo del hombre

62. J. BOCS, Puntos de vista, 30-31. 
no vino para ser servido, sino para servir y para dar su vida en rescate por muchos» (Mt 20, 26-28). "Pues si predico el Evangelio, no tengo de qué gloriarme; porque me es impuesta necesidad de hacerlo; $Y$ lay de $\mathrm{mi}$ si no predicare el Evangelio!» (1 Cor 9,16).

En síntesis, una de las sombras más intensas que se proyecta sobre el capítulo tercero de la Lumen Gentium es, sin género de duda, la ausencia de reinterpretación de la figura del papa.

/Sombras y Luces! Las dos realidades se encuentran presentes en el capítulo tercero de la Lumen Gentium. Si intensas son las luces, intensas son también las sombras. Lo cual indica que la tarea está sin terminar. Como miembros de la iglesia católica romana estamos todos comprometidos en conseguir que la luz se imponga a la tiniebla. Para conseguirlo, es necesario reconocer, en actitud de conversión, nuestras limitaciones y nuestros errores. La conversión lleva consigo dos movimientos: un movimiento de despojo y otro movimiento de enriquecimiento. Como iglesia, creyente en Cristo, tenemos que despojarnos de todo aquello que no responde a un sentido netamente evangélico. $Y$ enriquecernos, siempre en un proceso inacabado, de todo aquello que constituye el ideal del Evangelio.

Para terminar, y como síntesis apretada de todo lo que aquí se recoge, unas observaciones del ya frecuentemente citado Juan Bocs:

«Al terminar este examen del capítulo tercero de la constitución se impone una doble observación: El texto manifiesta, de manera evidente, un esfuerzo considerable por revisar el problema de las estructuras de la iglesia dentro de la línea eclesiológica trazada en el capítulo I sobre el ministerio. Lo mismo, cuando se trata de la colegialidad que de la exposición de los ministerios, es constante la referencia a la acción de Cristo y a la moción del Espíritu Santo, así como la realidad de comunión de la iglesia. Pero al mismo tiempo se percibe, casi en cada página la resistencia del peso institucional y el temor a dejarse arrastrar por una corriente demasiado impetuosa. No hay duda de que esto es muy explicable, dada la diversidad de tendencias que se expresaban en el concilio y la importancia del cambio de orientación que aparecía en el horizonte. Hay que reconocer el paso considerable que se ha dado, sabiendo que normalmente $-y$ en esto estarían de acuerdo no pocos padres $y$ teólogos - no podía tratarse más que de una etapa primera» ${ }^{63}$.

Estas palabras, ponderadas y objetivas, constituyen broche de oro para todo lo que yo he intentado reflejar en este artículo. Un juego de luces y sombras, en el que aparece tanto lo positivo como lo negativo. Me alegro de lo primero. Lamento y critico lo segundo. Todo ello en la seguridad de realizar una colaboración lo más fecunda posible para superar las deficiencias, todavía grandes, que aún se encuentran en muchos puntos de la eclesiología católica romana. El concilio, por tanto, no puede ser, ni en éste ni en otros campos, un

63. J. BOCS, Puntos de vista, 36-37. 
punto de llegada. Tiene que ser, por necesidad ineludible, un punto de partida. Sobre las bases que él presentó, se debe seguir construyendo, a fin de que la iglesia católica romana adquiera esos perfiles netamente evangélicos que la haga ser, de verdad, sacramento de la unión de Dios con los hombres y de los hombres entre sí.

Benito DOMINGUEZ SÁNCHEZ 